\title{
Estimating Invertebrate Response to Changes in Total Nitrogen, Total Phosphorus, and Specific Conductance at Sites Where Invertebrate Data are Unavailable
}
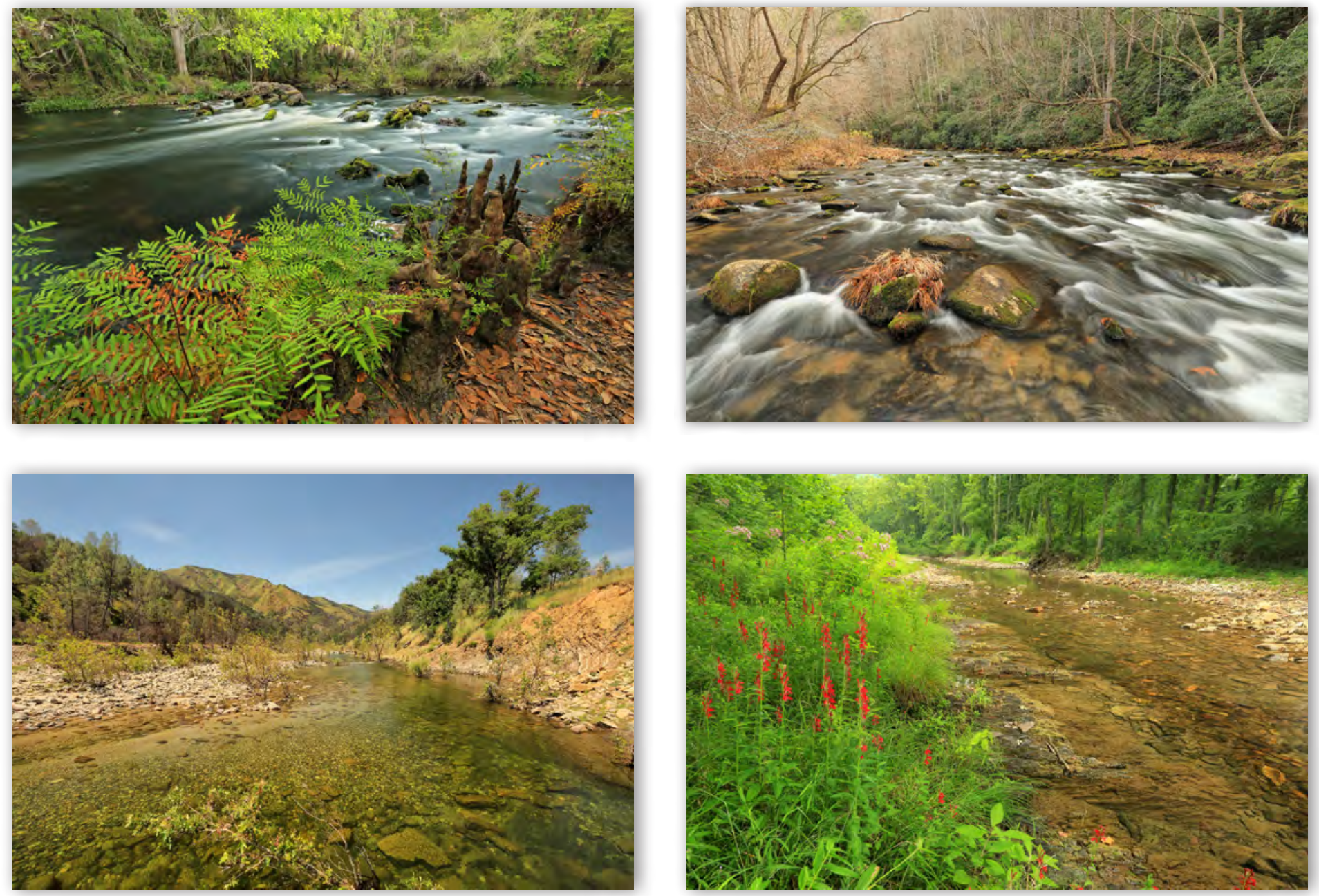

Scientific Investigations Report 2021-5070 
Cover. Top left photo: Hillsborough River, Hillsborough River State Park, Hillsborough County, Florida. Photograph by Alan M. Cressler, U.S. Geological Survey, 2016. Top right photo: Nantahala River, Nantahala National Forest, Macon County, North Carolina. Photograph by Alan M. Cressler, U.S. Geological Survey, 2017. Bottom left photo: Nacimiento River, San Luis Obispo County, California. Photograph by Alan M. Cressler, U.S. Geological Survey, 2017. Bottom right photo: Back Creek, Bath County, Virginia. Photograph by Alan M. Cressler, U.S. Geological Survey, 2014. 


\section{Estimating Invertebrate Response to Changes in Total Nitrogen, Total Phosphorus, and Specific Conductance at Sites Where Invertebrate Data are Unavailable}

By Robert E. Zuellig and Daren M. Carlisle

National Water Quality Program

Scientific Investigations Report 2021-5070 


\section{U.S. Geological Survey, Reston, Virginia: 2021}

For more information on the USGS - the Federal source for science about the Earth, its natural and living resources, natural hazards, and the environment—visit https://www.usgs.gov or call 1-888-ASK-USGS.

For an overview of USGS information products, including maps, imagery, and publications, visit https://store.usgs.gov/.

Any use of trade, firm, or product names is for descriptive purposes only and does not imply endorsement by the U.S. Government.

Although this information product, for the most part, is in the public domain, it also may contain copyrighted materials as noted in the text. Permission to reproduce copyrighted items must be secured from the copyright owner.

Suggested citation:

Zuellig, R.E., and Carlisle, D.M., 2021, Estimating invertebrate response to changes in total nitrogen, total phosphorus, and specific conductance at sites where invertebrate data are unavailable: U.S. Geological Survey Scientific Investigations Report 2021-5070, 24 p., https://doi.org/10.3133/sir20215070.

Associated data for this publication:

Zuellig, R.E., and Carlisle, D.M., 2021, Datasets for estimating invertebrate response to changes in total nitrogen, total phosphorus, and specific conductance at sites where invertebrate data are unavailable: U.S. Geological Survey data release, https://doi.org/10.5066/P9SMFACO.

ISSN 2328-0328 (online 


\section{Contents}

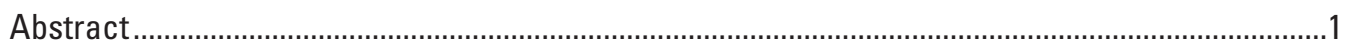

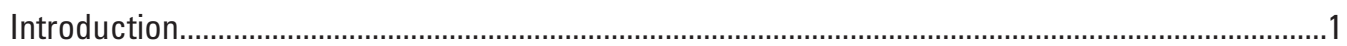

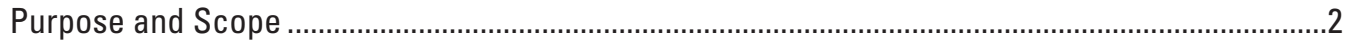

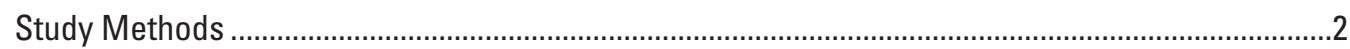

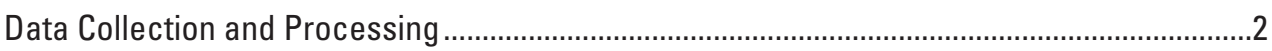

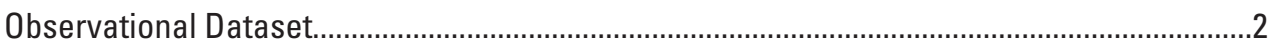

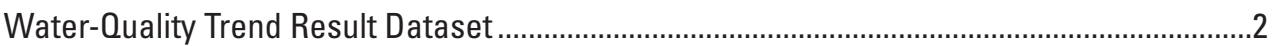

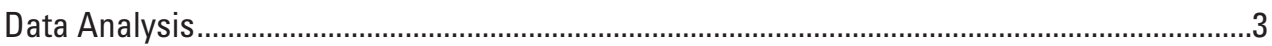

Stratifying Sites using Propensity Score Analysis ........................................................

Describing Invertebrate Response to Total Nitrogen, Total Phosphorus, and Specific Conductance by Fitting Generalized Additive and Generalized Linear Models ........................................................................................................

Estimation of Changes in Invertebrate Taxa Richness at Sites with Known Water-Quality Trends .........................................................................................

Effectiveness of Propensity Score-Based Stratification ...................................................................

Modeling Invertebrate Response to Total Nitrogen, Total Phosphorus, and Specific

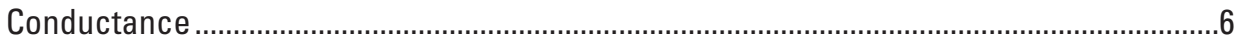

Invertebrate Response to Total Nitrogen and Total Phosphorus ...............................................8

Invertebrate Response to Specific Conductance ……….....................................................

Estimated Changes in Invertebrate Richness at Sites with Known Trends in Water Quality ...........9

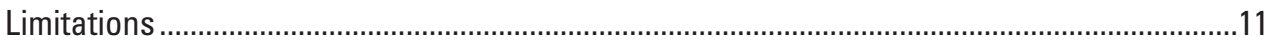

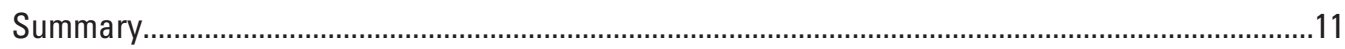

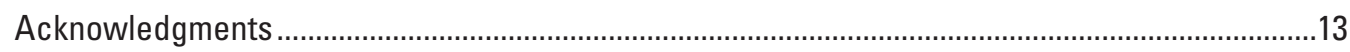

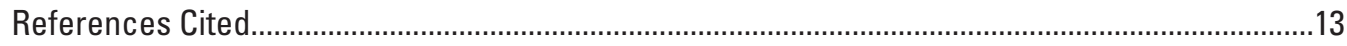

Appendix 1. Covariate Definitions and Data Characteristics for each Propensity

Score-Based Stratum ...................................................................................................17

Appendix 2. Graphical Representation of Invertebrate Response to Total Nitrogen, Total Phosphorus, and Specific Conductance ………………..............................................22

\section{Figures}

1. Graphs showing example variation among propensity score-based strata (A-F) of selected covariates used in the specific conductance random forests model ............6

2. Maps of the United States showing the distribution of sites within each propensity score-based stratum (A-F) for the total nitrogen, total phosphorus, and specific conductance random forests models.

3. Graphs showing estimated effects of total nitrogen (TN), total phosphorus (TP), and specific conductance (SC) on invertebrate taxa richness presented as the number of invertebrate taxa per natural log unit change in TN, TP, or SC concentration.

4. Graphs showing the estimated change in invertebrate taxa richness in response to percentage change in total nitrogen, total phosphorus, and specific conductance concentration at selected sites with known water-quality trends reported by Oelsner and others (2017). 
5. Maps of the United States showing estimated change in the number of taxa at selected sites with known trends in total nitrogen, total phosphorus, and specific conductance between 1992 and 2012 reported by Oelsner and others (2017)

\section{Tables}

1. Spearman's rank correlation values between the covariates and observed total nitrogen values.

2. Spearman's rank correlation values between the covariates and observed total phosphorus values

3. Spearman's rank correlation values between the covariates and observed specific conductance values.

\section{Conversion Factors}

International System of Units to U.S. customary units

\begin{tabular}{|c|c|c|}
\hline Multiply & By & To obtain \\
\hline \multicolumn{3}{|c|}{ Length } \\
\hline centimeter (cm) & 0.3937 & inch (in.) \\
\hline millimeter (mm) & 0.03937 & inch (in.) \\
\hline meter $(\mathrm{m})$ & 3.281 & foot (ft) \\
\hline kilometer (km) & 0.6214 & mile (mi) \\
\hline meter $(\mathrm{m})$ & 1.094 & yard (yd) \\
\hline \multicolumn{3}{|c|}{ Area } \\
\hline square kilometer $\left(\mathrm{km}^{2}\right)$ & 247.1 & acre \\
\hline square kilometer $\left(\mathrm{km}^{2}\right)$ & 0.3861 & square mile $\left(\mathrm{mi}^{2}\right)$ \\
\hline \multicolumn{3}{|c|}{ Mass } \\
\hline kilogram (kg) & 2.205 & pound avoirdupois (lb) \\
\hline
\end{tabular}

\section{Datum}

Horizontal coordinate information is referenced to the North American Datum of 1983 (NAD 83).

Elevation, as used in this report, refers to distance above the vertical datum.

\section{Supplemental Information}

Specific conductance is given in microsiemens per centimeter at 25 degrees Celsius $(\mu \mathrm{S} / \mathrm{cm}$ at $\left.25^{\circ} \mathrm{C}\right)$.

Concentrations of chemical constituents in water are given in either milligrams per liter (mg/L) or micrograms per liter $(\mu \mathrm{g} / \mathrm{L})$. 


\section{Abbreviations}

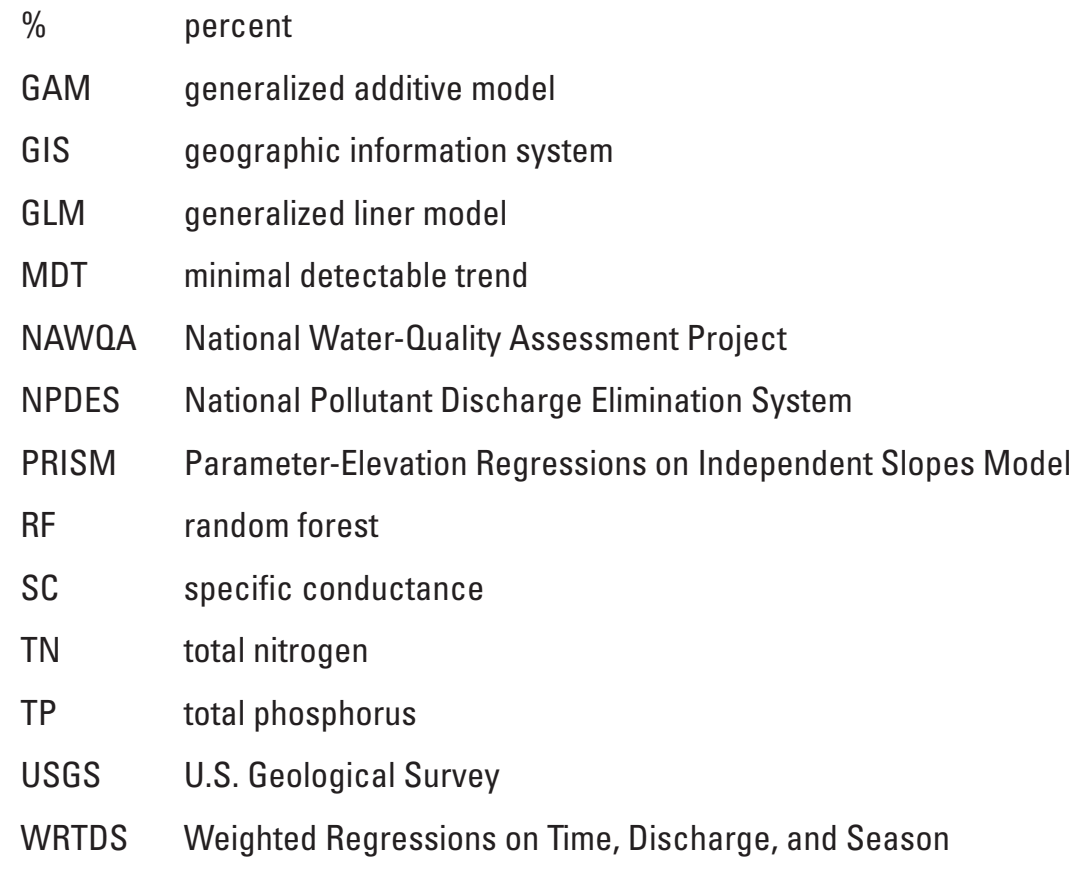

WRTDS Weighted Regressions on Time, Discharge, and Season 



\title{
Estimating Invertebrate Response to Changes in Total Nitrogen, Total Phosphorus, and Specific Conductance at Sites Where Invertebrate Data are Unavailable
}

\author{
By Robert E. Zuellig and Daren M. Carlisle
}

\section{Abstract}

The purpose of this report is to describe a possible approach to estimate changes in invertebrate taxa richness at sites with known water-quality trends but no invertebrate data. In this study, data from 1,322 sites were used to describe invertebrate response to changes in total nitrogen, total phosphorus, or specific conductance, and to estimate changes in invertebrate taxa richness at 259 sites with reported water-quality trends but no invertebrate data. Sites were stratified using propensity score analysis to control for confounding factors (for example, climate, land use, land cover). Generalized linear models were developed to describe changes in invertebrate taxa richness along gradients of total nitrogen, total phosphorus, and specific conductance values. The magnitude and direction of invertebrate response to gradients of water quality varied among parameters and strata, with changes in invertebrate taxa richness per natural log unit change in concentration ranging from -7 to +6 . However, estimated changes in invertebrate taxa richness at sites with known water-quality trends were much less and did not exceed three taxa until changes in concentration were greater than 50 percent. Applying this approach provides (1) a first screening to identify where changes in invertebrate taxa richness are likely to occur and (2) the necessary groundwork to improve estimation of invertebrate response to trends in water quality where biological data are lacking.

\section{Introduction}

Development and industrialization across the United States resulted in deteriorating water quality in rivers and streams and ultimately led to the enactment of the 1972 Clean Water Act and its many amendments (86 Stat. 816, 33 U.S.C. $\S 1251$ et seq.). The primary goal of the Clean Water Act is to "restore and maintain the chemical, physical, and biological integrity of the Nation's waters" ( $\$ 1251[\mathrm{a}])$. Although many water-quality monitoring programs have integrated a biological component, detecting changes (trends) in chemical parameters is the primary goal of water-monitoring programs in the United States (Myers and Ludtke, 2017). For example, measured water-quality values are often compared to chemical criteria developed through toxicological laboratory studies to determine if regulatory water-quality standards are being exceeded (Barclay and others, 2016; Runkel and others, 2016). As a result, programs often collect water-quality data in the absence of biological data. Focus on changes in water quality has led to sophisticated statistical methods capable of detecting minute changes in concentration (Hirsch and others, 2010, 2015; Ryberg and Vecchia, 2013; Hirsch and DeCicco, 2015; Murphy and Sprague, 2019). In general, these methods adjust trend estimates to account for the influence of streamflow on concentration during a specified trend period. Water-quality trend studies typically place results in the context of ecological effects by assessing changes in concentration during a specified time period relative to a baseline, benchmark, or starting condition (for example, Shoda and others, 2019), but rarely evaluate ecological relevance by concurrently measuring the biota. Monitoring water quality with the intent to understand how aquatic communities respond to water-quality conditions without directly measuring them can lead to a false understanding of ecologically relevant changes in water quality. There are many examples where chemical criteria developed through toxicological laboratory studies may fail to protect aquatic communities (Pacheco and others, 2005; Schmidt and others, 2011; Beketov and others, 2013; Clements and Kotalik, 2016).

In the absence of directly measuring a biological response associated with a water-quality trend, it may be possible to use observational data to estimate the biological change given a known change in water-quality concentration. The U.S. Geological Survey (USGS) has accumulated thousands of water-quality measurements and associated invertebrate data from sites across the United States as part of the National Water-Quality Assessment Project (NAWQA) of the National Water Quality Program (Gilliom and others, 1995). These data can be used to estimate a biological response to changes in water quality. Additionally, Wieczorek and others (2018) derived 250 geographic information system (GIS) watershedscale descriptors of natural and anthropogenic features (for example, climate, geology, soils, hydrology, land use) as part of NAWQA. Finally, Oelsner and others (2017) published 
water-quality trend results of more than 11,000 site, constituent, and trend-period combinations for the United States. Collectively, these data provide the basis to estimate invertebrate response to known changes in water-quality conditions during a specified time period at sites where invertebrate data are lacking. All data used in this report were compiled from existing USGS databases or publications as described herein and are available in the USGS data release associated with this report (Zuellig and Carlisle, 2021).

\section{Purpose and Scope}

The purpose of this report is to describe a possible approach to estimate changes in invertebrate taxa richness at sites with known water-quality trends but no invertebrate data. Publicly available USGS NAWQA water-quality, invertebrate, and GIS data for 1,322 sites were compiled, and the sites were stratified into groups based on environmental similarity as identified by a propensity score analysis. Changes in invertebrate taxa richness in response to changes in total nitrogen (TN), total phosphorus (TP), and specific conductance (SC) concentration were described for each stratum using regression techniques. Regression results were used to estimate expected changes in invertebrate taxa richness at 259 sites that lacked invertebrate data but had known changes in TN, TP, or SC concentration as reported by Oelsner and others (2017).

\section{Study Methods}

\section{Data Collection and Processing}

Invertebrate samples were collected from targeted habitats with the greatest taxa richness (riffles or woody snags) along predefined stream reaches during low-flow periods following established protocols (Cuffney and others, 1993; Fitzpatrick and others, 1998; Moulton and others, 2002). Samples were preserved in the field and shipped to the USGS National Water Quality Laboratory in Denver, Colorado, where they were processed using protocols detailed in Moulton and others (2000). Invertebrates were identified to the lowest practical taxonomic resolution (usually genus) and enumerated. Quality assurance of sorting efficiency and identification accuracy were evaluated as described in Moulton and others (2000).

Several steps were taken to prepare the invertebrate data for analysis:

- Names were harmonized to account for changes in taxonomy that occurred between 1993 and 2016.

- Species names were reduced to genus.

- Counts of larvae, pupae, and adults with the same name, and others with unique names, were summed by sample.
- Ambiguous taxa (that is, individuals not identified to the targeted level) were resolved by keeping only those unique within each sample.

- Raw data counts were standardized to 300 for each sample by randomly resampling individuals without replacement until a 300 count was reached.

- Invertebrate taxa richness was calculated as the sum of unique names identified in each sample.

Total nitrogen and TP were sampled, and SC measured using standardized methods (USGS, variously dated). In general, multiple liters of water were composited from depth- or width-integrated samples. Composited volumes were split and preserved in the field and shipped to the USGS National Water Quality Laboratory for analyses. Data quality was maintained through adherence to quality-assurance plans and qualitycontrol samples (for example, replicates, field blanks, spikes). Specific conductance was measured from split samples or from handheld instruments placed directly in the stream.

\section{Observational Dataset}

Observational data consisting of invertebrate and waterquality (TN, TP, and SC) sample results collected between 1993 and 2016 were downloaded from the USGS BioDataAquatic Bioassessment Data for the Nation (USGS, 2020) and National Water Information System (https://doi.org/ 10.5066/F7P55KJN) databases. Invertebrate samples were paired with TN, TP, and SC samples collected at the same site within 60 days of invertebrate sampling. A single sample was randomly selected for sites where multiple samples were collected on the same date. Only invertebrate samples paired with all three water-quality parameters within the 60 -day period were retained. Although the window for pairing samples was 60-days, 8 was the mean number of days between invertebrate and water-quality sampling. Selected GIS-derived variables from Wieczorek and others (2018) were appended to each set of samples (observations by location). The 250 selected GIS-derived variables included reach, riparian buffer, and watershed-scale descriptors of natural and anthropogenic features broadly defined as climate, geology, soils, hydrology, and land use. This selection process resulted in 1,322 unique sites represented by a single set of observations and distributed across the conterminous United States (Zuellig and Carlisle, 2021).

\section{Water-Quality Trend Result Dataset}

A second dataset was compiled for selected sites with known trends in TN, TP, or SC between 1992 to 2012 reported by Oelsner and others (2017) as part of the most comprehensive and recent assessment of surface-water-quality trends in the United States. Oelsner and others (2017) generated water-quality trend results by the Weighted Regressions on Time, Discharge, and Season (WRTDS) method first described 
by Hirsch and others (2010) and later detailed by Hirsch and DeCicco (2015) and Murphy and Sprague (2019). A likelihood statistic (equivalent to a two-sided $p$-value) and 90-percent confidence intervals were generated on the magnitude (percentage change in concentration) of the trend as part of the WRTDS method using a bootstrap routine described by Hirsch and others (2015). The WRTDS method applied by Oelsner and others (2017) removed the influence of both random and systematic variation in streamflow on concentration. When a systematic trend in streamflow is absent, the flow-normalized result represents the water-quality trend experienced by the biota in the stream (Oelsner and others, 2017).

Conversely, when a systematic streamflow trend is present, the flow-normalized results depart from what was experienced by the biota. So, to avoid inclusion of the systematic streamflow case in this study, trend results of Oelsner and others (2017) were screened for having a likelihood value greater than or equal to $(\geq) 0.95$ for cases with streamflow trends reported by Farmer and others (2017), and were visually reviewed to determine if the flow-normalized estimates in concentration departed from the nonflow-normalized results (Oelsner and others, 2017, app. 6). Additionally, each trend result was paired with the full list of covariates (Wieczorek and others, 2018) including water quality, where TN, TP, and $\mathrm{SC}$ values were randomly selected from samples collected in the first year of the trend period. This screening process resulted in 322 trend results from 259 unique sites (Zuellig and Carlisle, 2021). These flow-normalized changes in concentration represent the water-quality trend experienced by the biota in the stream, but not necessarily the full range of concentrations or duration of exposures during the trend period.

\section{Data Analysis}

The main objective of this report is to estimate changes in invertebrate taxa richness at sites with known water-quality trends, but where invertebrate data were unavailable. Meeting this goal required independently applying a series of analytical steps for each water-quality parameter (TN, TP, and SC). In brief, the 1,322 sites in the observational dataset were grouped into separate strata, where sites within each stratum shared similar environmental characteristics. Second, statistical models for each stratum were constructed to describe invertebrate response to TN, TP, and SC. Third, results from the statistical models were used to estimate changes in invertebrate taxa richness at the 259 sites in the water-quality trend result dataset. All data used for analysis are available in Zuellig and Carlisle (2021).

\section{Stratifying Sites using Propensity Score Analysis}

Propensity score analysis was used to stratify sites, control for covariates (Rosenbaum and Rubin, 1984), and isolate the effect of TN, TP, and SC on invertebrate taxa richness. Propensity score analysis is widely used in epidemiology, sociology, and economics (Austin, 2011), and has occasionally been used to address ecological questions (Yuan and others, 2009; Yuan, 2010). In general, propensity scores are calculated using a predictive model where covariates are used to estimate the factor of interest (herein, TN, TP, or SC). For example, SC can be estimated as a function of covariate values where the mean estimated SC value for each site is the propensity score. In theory, sites with similar estimated values are similar with respect to covariate values (Austin, 2011), and this theory is the basis for stratification of sites in this study. Stratifying observations based on propensity scores places sites into groups that are similar in covariate distribution but vary along the TN, TP, or SC concentration gradient.

Propensity scores were calculated for TN, TP, and SC by constructing separate random forests $(\mathrm{RF})$ prediction models (Cutler and others, 2007) using selected GIS and water-quality parameters from the 1,322 sites in the observational dataset as covariates. Before analysis, 11 to 13 covariates were selected for each RF prediction model, including measures of climate, soils, land use and land cover, and watershed topology (app. 1, table 1.1). Water-quality covariates (TN, TP, or SC) were included in each RF model but only when that covariate was not the parameter being predicted. For example, TN and TP were included as covariates in the RF model predicting SC, TP and SC were included in the model predicting TN, and SC and TN were included in the model predicting TP. Covariate selection for each RF analysis was based on covariates that have been shown to either influence invertebrate taxa richness or TN, TP, and SC at local and (or) regional scales (Yuan, 2010; Clements and Kotalik, 2016). The RF prediction models were completed using the random forest package in $\mathrm{R}$ (The $\mathrm{R}$ Foundation, 2014).

The propensity scores were divided into five, six, and seven strata based on evenly spaced percentiles and were iteratively evaluated for effectiveness of each stratification scheme by comparing Spearman's rank correlation coefficient values among covariates within each stratum relative to values among covariates in the full dataset. Ideally, propensity score-based stratification should lead to weaker correlations within the strata relative to the full dataset (Yuan, 2010). After several iterations, sites were stratified into six groups for further analysis.

\section{Describing Invertebrate Response to Total Nitrogen, Total Phosphorus, and Specific Conductance by Fitting Generalized Additive and Generalized Linear Models}

Using the observational dataset, estimated effects of TN, $\mathrm{TP}$, and SC on invertebrate taxa richness were determined by fitting generalized additive models (GAMs) and generalized linear models (GLMs) for each stratum given a selected set of covariates. Within each stratum, the most parsimonious solution was sought that included the water-quality parameter while allowing for one or more covariates as predictors of invertebrate taxa richness. First, GAMs were constructed to 
allow for flexibility in the form of the response (for example, nonlinear or linear). The most parsimonious solution was determined by first fitting a GAM that included the waterquality parameter and all covariates, and then sequentially removing nonsignificant ( $p$ greater than $[>] 0.05$ ) covariates if doing so did not substantively increase the Akaike Information Criterion value relative to the previous solution. After selecting the most parsimonious GAM, the fitted relations were examined to determine whether GLMs using the same variables as nonlinear or linear terms were equally effective based on Akaike Information Criterion values. In all cases, GLMs were equally as effective in describing invertebrate response to TN, TP, and SC and were used as the final solutions to describe changes in invertebrate taxa richness at sites with known water-quality trends. All GAM and GLM solutions were completed using the car and mgcv packages in $\mathrm{R}$ (The $\mathrm{R}$ Foundation, 2014). Water-quality parameters (TN, TP, and SC) were natural log-transformed before analysis.

\section{Estimation of Changes in Invertebrate Taxa Richness at Sites with Known Water-Quality Trends}

The GLM coefficients for TN, TP, and SC were used to estimate expected changes in invertebrate taxa richness in response to trends in TN, TP, and SC concentration at the 259 sites in the water-quality trend result dataset selected from Oelsner and others (2017). The GLM coefficients represented the expected change in the number of invertebrate taxa (invertebrate taxa richness) per natural log unit change in TN, TP, or SC concentration, and were specific to each water-quality parameter and stratum. Therefore, the earlier RF models used to stratify the observational dataset were applied to stratify the 259 sites in the water-quality trend result dataset to identify the correct GLM coefficient value needed to estimate changes in invertebrate taxa richness for each trend result. Changes in water-quality concentrations from Oelsner and others (2017) were converted to changes in natural log units to align with the GLM coefficients. Estimated change in invertebrate taxa richness was calculated for each water-quality trend result by multiplying the appropriate GLM coefficient value by the natural $\log$ unit change in water-quality concentration.

\section{Effectiveness of Propensity Score-Based Stratification}

Within each stratum, TN, TP, and SC values varied at least an order of magnitude in most cases (app. 1, table 1.2), and the number of observations within each stratum ranged between 197 and 239, depending on the RF model (table 1, table 2, and table 3). Overall, the confounding influence of covariates on TN, TP, and SC was reduced by stratification. In nearly all cases, correlation between covariates and each water-quality parameter declined after the stratification process (tables 1-3). This was especially true for SC as only a few correlation values within strata were near 0.30 , and most were around 0.10 or less. Although most correlations were reduced by stratification, a few were higher within certain strata and water-quality parameters (tables $1-3$ ), although in these cases (tables 1-3, bolded values), the correlations were still relatively low (absolute values less than or equal to $[\leq] 0.30$, mean $=0.20)$ and considered weak (Cohen, 1988).

Table 1. Spearman's rank correlation values between the covariates and observed total nitrogen values. Values are presented for each propensity score-based stratum (A-F) and for the full dataset (Full data) for each covariate used to predict total nitrogen using random forests. Numbers in parentheses are the number of observations within each stratum. Bold values indicate correlation values that were greater within a stratum relative to the full dataset. See table 1.1 in appendix 1 for covariate definitions.

\begin{tabular}{lccrrrrr}
\hline \multicolumn{1}{c}{ Covariate } & Full data (1,322) & A (210) & B (217) & C (211) & D (211) & E (235) & F (238) \\
\hline TOT_N97 & 0.68 & 0.23 & -0.12 & -0.26 & -0.33 & -0.39 & 0.03 \\
TP & 0.62 & 0.19 & 0.03 & 0.05 & -0.18 & -0.12 & -0.03 \\
agproduction_1982 & 0.60 & 0.35 & -0.04 & -0.30 & -0.29 & -0.39 & -0.01 \\
TOT_NWALT12_43 & 0.59 & 0.26 & -0.14 & -0.33 & -0.29 & -0.39 & -0.01 \\
SLOPE_PCT_30M & -0.59 & -0.39 & 0.13 & 0.16 & 0.20 & 0.38 & 0.06 \\
agproduction_2002 & 0.57 & 0.35 & -0.05 & -0.29 & -0.30 & -0.39 & -0.01 \\
TOT_NLCD11_82_RIP50 & 0.55 & 0.15 & -0.15 & -0.24 & -0.33 & -0.35 & -0.01 \\
SC & 0.50 & 0.08 & -0.11 & -0.21 & -0.28 & -0.15 & 0.21 \\
TOT_NWALT12_21 & 0.30 & 0.21 & 0.10 & 0.15 & 0.08 & 0.15 & 0.08 \\
PPTAVG_BASIN & -0.23 & 0.18 & 0.09 & 0.23 & 0.17 & 0.20 & -0.08 \\
FST32F_BASIN & 0.16 & $\mathbf{0 . 3 0}$ & -0.11 & 0.12 & 0.09 & 0.06 & 0.03 \\
HGC & -0.15 & $\mathbf{0 . 2 6}$ & 0.06 & -0.05 & -0.15 & 0.05 & -0.05 \\
DRAIN_SQKM & -0.03 & 0.02 & 0.00 & $\mathbf{0 . 0 9}$ & $-\mathbf{0 . 1 0}$ & $\mathbf{- 0 . 0 5}$ & -0.10 \\
\hline
\end{tabular}


The distribution of covariates among strata reveal how sites were organized along multiple environmental gradients. For example, the covariates for SC characterized sites in stratum $\mathrm{A}$ as having low $\mathrm{TN}$, high precipitation (PPTAVG_BASIN), and more forested riparian corridors (TOT_NLCD11_42_RIP50) compared to other strata (fig. 1).

Conversely, sites in stratum $\mathrm{F}$ had high TN and low precipitation, riparian forest, and extended time for subsurface flow to reach the stream (CONTACT). Additionally, sites within strata were often geographically clustered. For example, TN, TP, and SC propensity scores (RF predicted values) were greatest among strata $\mathrm{E}$ and $\mathrm{F}$, which include sites that are mostly located within the north central part of the United States (fig. 2).

Likewise, sites on the low side of the TN and TP gradient (strata A and B) were mostly located among relatively high-elevation regions (fig. 2). Summary statistics for each covariate and stratum are provided in table 1.3, table 1.4, and table 1.5 in appendix 1.

Table 2. Spearman's rank correlation values between the covariates and observed total phosphorus values. Values are presented for each propensity score-based stratum (A-F) and for the full dataset (Full data) for each covariate used to predict total phosphorus using random forests. Numbers in parentheses are the number of observations within each stratum. Bold values indicate correlation values that were greater within a stratum relative to the full dataset. See table 1.1 in appendix 1 for covariate definitions.

\begin{tabular}{|c|c|c|c|c|c|c|c|}
\hline Covariate & Full data $(1,322)$ & $A(221)$ & B (197) & $C(216)$ & $D(215)$ & $E(234)$ & $F(239)$ \\
\hline $\mathrm{TN}$ & 0.62 & 0.25 & -0.31 & -0.40 & -0.37 & -0.19 & 0.14 \\
\hline NO10AVE & 0.53 & 0.18 & -0.18 & -0.10 & -0.12 & -0.17 & -0.04 \\
\hline SLOPE_PCT_30M & -0.45 & -0.28 & 0.18 & 0.25 & 0.27 & 0.02 & 0.17 \\
\hline $\mathrm{SC}$ & 0.44 & 0.07 & -0.18 & -0.18 & -0.43 & -0.16 & 0.02 \\
\hline TOT_NPDES_MAJ_DENS & 0.20 & -0.13 & -0.20 & -0.14 & -0.05 & -0.14 & 0.19 \\
\hline SILTAVE & 0.24 & -0.03 & 0.09 & -0.02 & -0.17 & -0.14 & -0.01 \\
\hline LST32F_BASIN & -0.10 & -0.16 & 0.16 & 0.07 & -0.11 & 0.04 & 0.00 \\
\hline DRAIN_SQKM & 0.10 & -0.15 & -0.08 & 0.08 & -0.10 & -0.07 & 0.06 \\
\hline FST32F_BASIN & 0.05 & 0.16 & -0.14 & -0.01 & 0.16 & -0.01 & 0.00 \\
\hline
\end{tabular}

Table 3. Spearman's rank correlation values between the covariates and observed specific conductance values. Values are presented for each propensity score-based stratum (A-F) and for the full dataset (Full data) for each covariate used to predict specific conductance using random forests. Numbers in parentheses are the number of observations within each stratum. Bold values indicate correlation values that were greater within a stratum relative to the full dataset. See table 1.1 in appendix 1 for covariate definitions.

$[\mathrm{ND}$, not detected]

\begin{tabular}{|c|c|c|c|c|c|c|c|}
\hline Covariate & Full data $(1,322)$ & $A(209)$ & B (214) & $C(210)$ & $D(215)$ & $E(235)$ & $F(239)$ \\
\hline RECHARGE & -0.62 & -0.12 & 0.07 & 0.18 & 0.05 & 0.32 & 0.01 \\
\hline pmpe & -0.61 & -0.08 & 0.03 & 0.23 & 0.12 & 0.28 & -0.06 \\
\hline TOT_NLCD11_42_RIP50 & -0.57 & 0.01 & 0.18 & 0.03 & 0.12 & -0.08 & 0.20 \\
\hline WD_FEB_BASIN & -0.53 & 0.10 & 0.15 & 0.06 & 0.06 & 0.22 & 0.03 \\
\hline CONTACT & 0.44 & 0.24 & -0.07 & -0.02 & 0.00 & -0.04 & -0.19 \\
\hline TP & 0.44 & 0.20 & 0.04 & -0.14 & -0.11 & -0.06 & -0.03 \\
\hline SLOPE_PCT_30M & -0.36 & -0.14 & 0.09 & 0.00 & 0.03 & -0.07 & 0.29 \\
\hline S_pct & 0.31 & -0.07 & -0.08 & 0.07 & 0.04 & -0.03 & 0.14 \\
\hline FST32F_BASIN & -0.24 & 0.04 & 0.11 & 0.18 & 0.01 & 0.03 & -0.08 \\
\hline
\end{tabular}



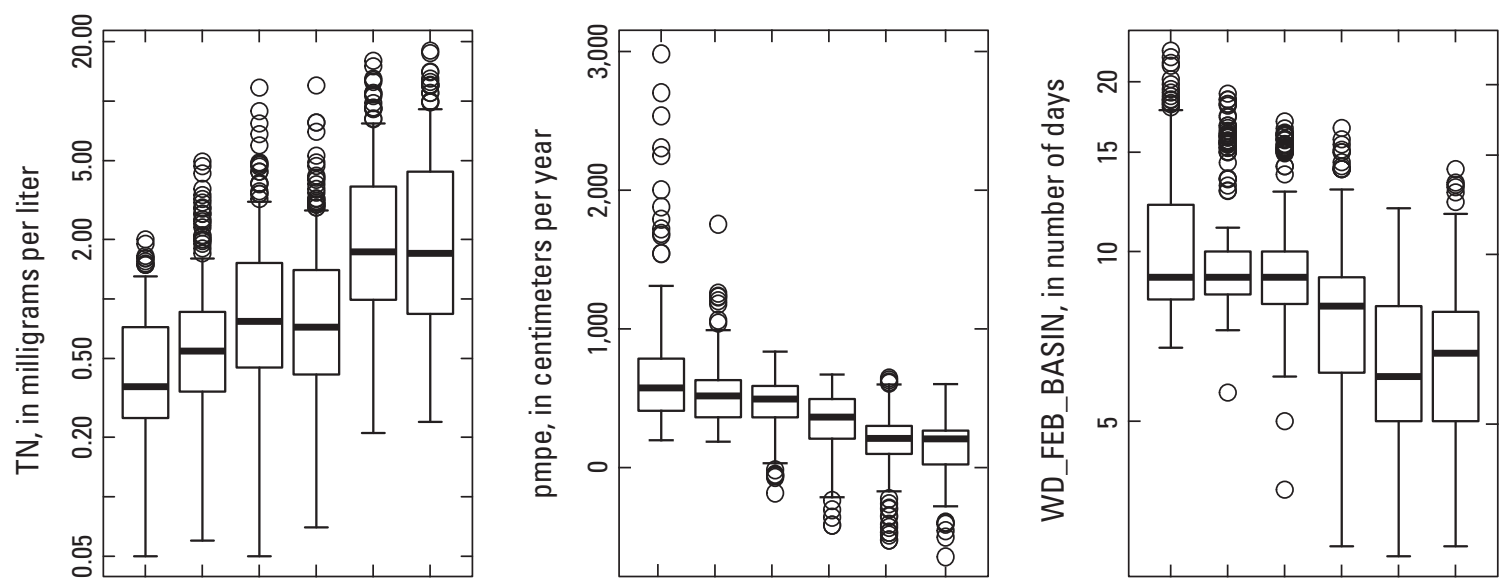

EXPLANATION
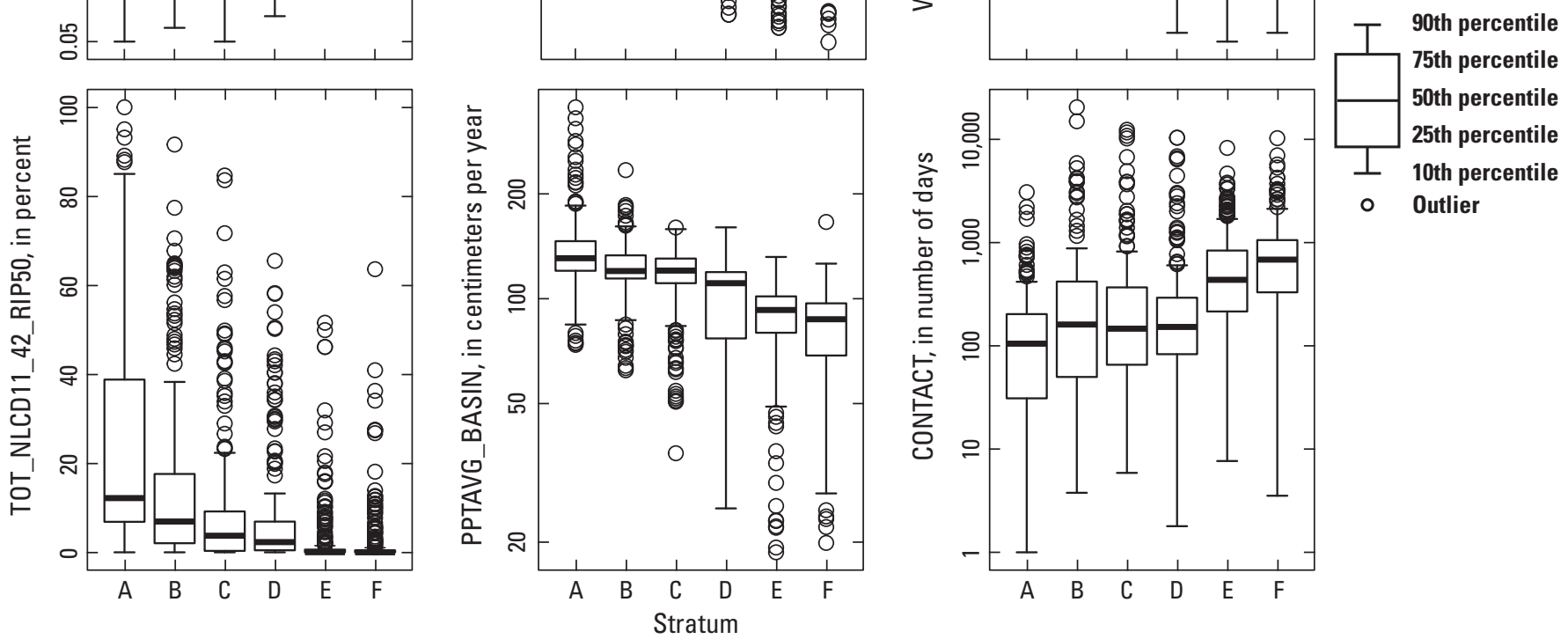

Figure 1. Graphs showing example variation among propensity score-based strata $(A-F)$ of selected covariates used in the specific conductance random forests model. See table 1.1 in appendix 1 for covariate definitions and units. Note log scale for TN, WD_FEB_ BASIN, PPTAVG_BASIN, and CONTACT.

\section{Modeling Invertebrate Response to Total Nitrogen, Total Phosphorus, and Specific Conductance}

Generalized linear models that described the response of invertebrate taxa richness to TN, TP, and SC were statistically significant $(p<0.05)$ for some propensity score-based strata but varied by water-quality parameter. For example, of the 18 possible cases (6 strata and 3 water-quality parameters), 10 models were statistically significant ( 3 for TN, 2 for TP, and 5 for SC; fig. 3). Overall, GLMs described up to 46 percent of the variance in invertebrate taxa richness (mean was 28 percent, with a range of 18 to 46 percent). Graphical representations of invertebrate response to TN, TP, and SC are provided for each stratum in appendix 2 (figs. 2.1, 2.2, and 2.3).

Modeling the response of invertebrate taxa richness to TN, TP, and SC proved difficult within several strata, which can be attributed to at least three factors as described in the following paragraphs.
First, the clumped spatial distribution of observed data required a nationally scaled RF model for each water-quality parameter, rather than smaller-scaled regional models.

Although several key environmental covariates were controlled for in each RF analysis (tables 1-3), other factors, such as biogeographic distribution of certain invertebrate groups, likely increased the heterogeneity and complexity in richness across the study area. Stratification forced the spatially clumped sites into one of six strata (fig. 2) possibly making it challenging to account for variability in richness at this large geographic scale. Greater data density may have allowed for regionally based stratification and subsequent smaller scaled GLMs, and smaller geographically scaled GLMs may have captured finer details that influence invertebrate taxa richness and better isolated the response to TN, TP, and SC.

A second reason for difficulty within some strata was the potential influence of unmeasured confounding factors (covariates). A wide range of covariates were considered that likely did not bias RF predictions because of correlations between each water-quality parameter, and covariates 
Total nitrogen

Total phosphorus
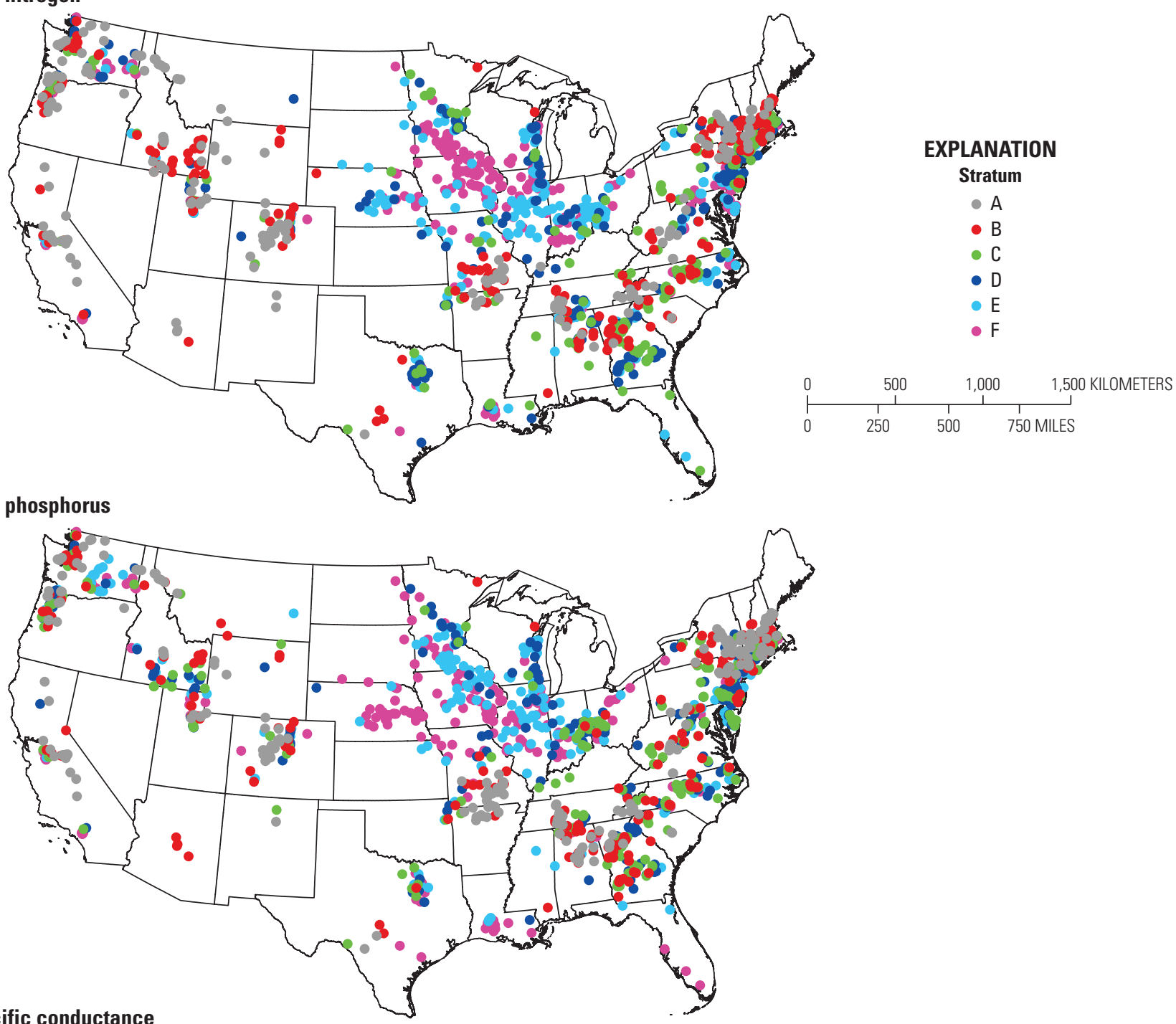

Specific conductance

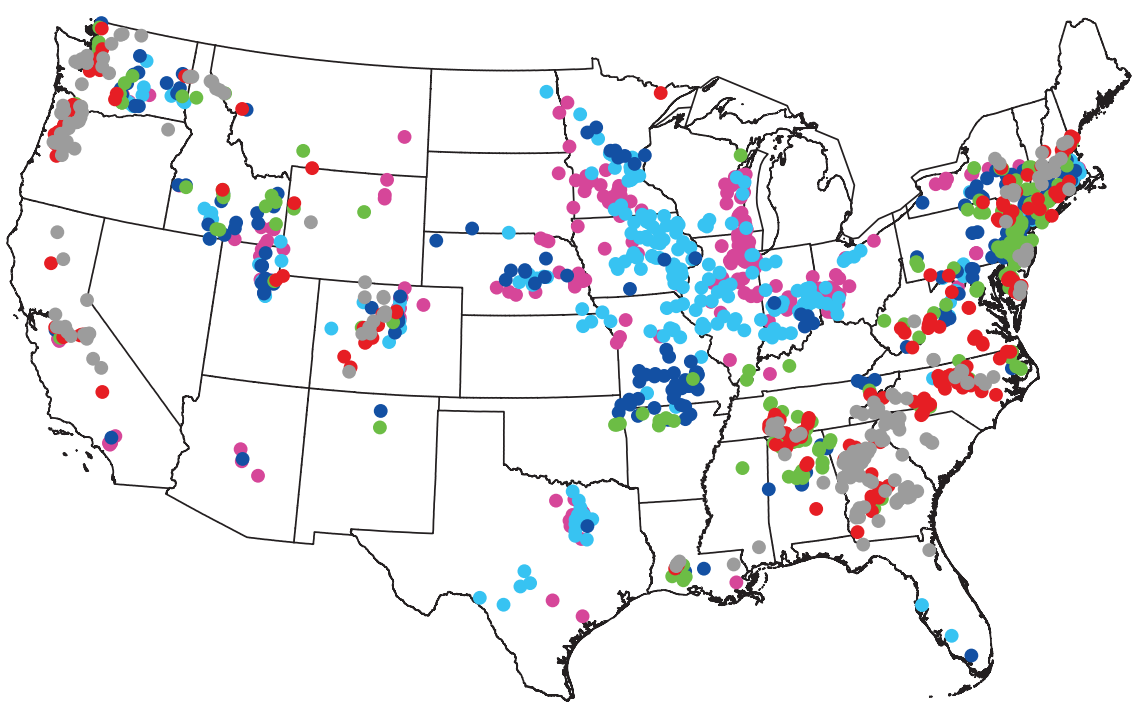

Figure 2. Maps of the United States showing the distribution of sites within each propensity score-based stratum (A-F) for the total nitrogen, total phosphorus, and specific conductance random forests models. 


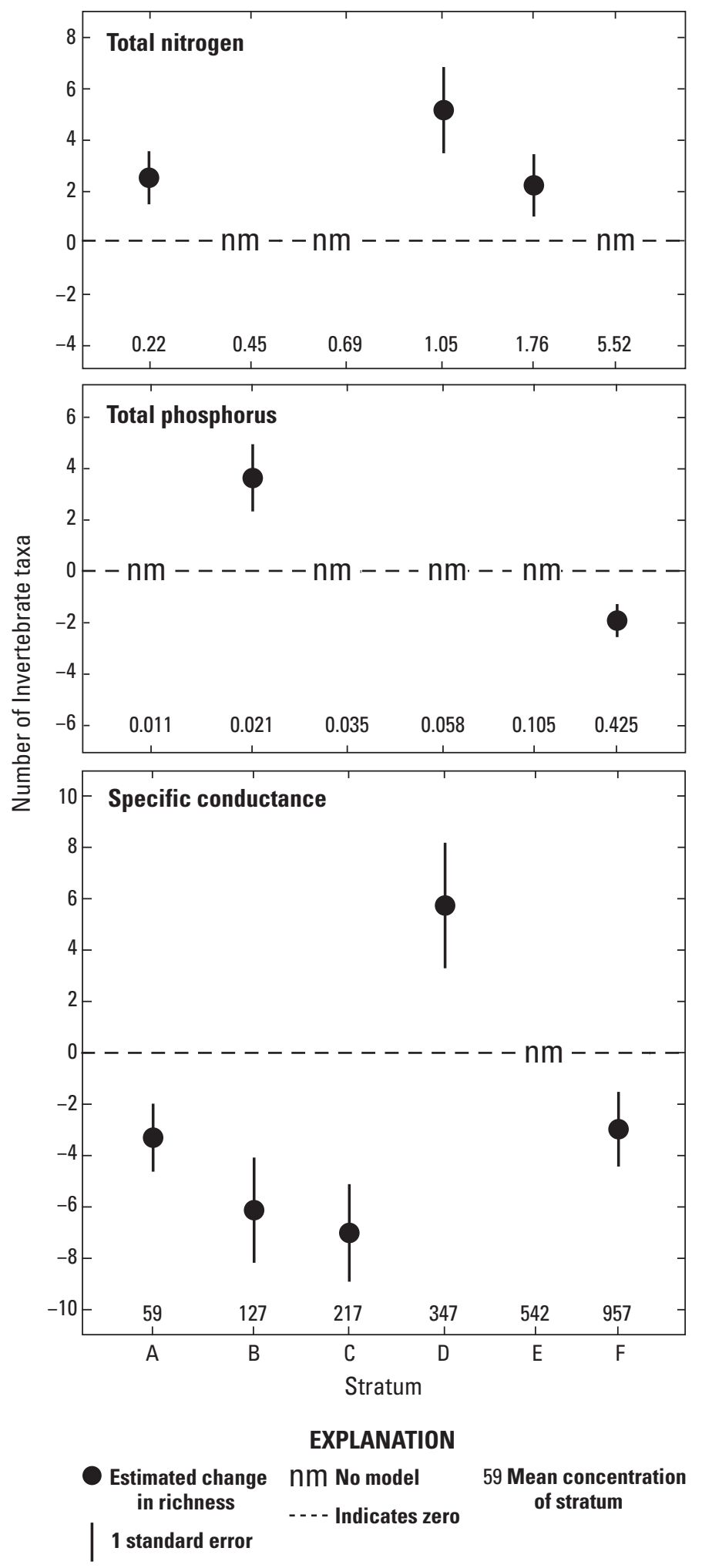

within strata were much weaker when compared to the full dataset (tables 1-3) or were considered weak (Cohen, 1988). Stratifying sites based on propensity scores grouped sites that differed in TN, TP, and SC concentrations but were similar in covariate structure, which was necessary to isolate invertebrate response to water-quality gradients within strata. However, propensity score analysis only controls for the covariates included in the analysis. Measures of substrate size and other stream chemistry (for example, major ions) were unavailable, but may have helped better illustrate the response of invertebrate taxa richness (Schmidt and others, 2019) to TN, TP, or SC in the strata for which it was difficult to fit statistically significant GAMs or GLMs.

Third, it is possible that richness simply wasn't influenced by TN, TP, or SC in certain strata as invertebrate response to stressors is often context dependent (Clements and others, 2015; Clements and Kotalik, 2016). For example, many of the sites in this study may have harbored inherently tolerant invertebrate communities because they were heavily influenced by human disturbance or located in regions with naturally harsh conditions (Millward and Klerks, 2002; Zuellig and Schmidt, 2012). In these cases, the water-quality gradient within strata may not have been great enough to consistently induce changes in invertebrate taxa richness (gain or loss of taxa) or the other metrics examined but not reported (for example, multimetric index; ratio of observed to expected taxa; the number of mayfly, stonefly, and caddisfly taxa; tolerance indicator values; total invertebrate abundance). A combination of greater data density, geographically smaller-scaled analysis, additional covariates, and greater range in concentrations may have increased the ability to better describe invertebrate response to TN, TP, and SC among and within strata. Incorporating data from other agencies (for example, State and Tribal agencies, and the U.S. Environmental Protection Agency and other Federal agencies) in future efforts may help with many of these issues.

\section{Invertebrate Response to Total Nitrogen and Total Phosphorus}

The magnitude and direction of invertebrate response to TN and TP varied substantially across water-quality parameters and strata (fig. 3). Taxa richness increased between 2.8 to 5.3 taxa per natural log unit increase of $\mathrm{TN}$; whereas, richness increased by 3.7 taxa and decreased by 1.9 taxa in response to increased TP.

Figure 3. Graphs showing estimated effects of total nitrogen (TN), total phosphorus (TP), and specific conductance (SC) on invertebrate taxa richness presented as the number of invertebrate taxa per natural log unit change in TN, TP, or SC concentration. Estimated effects are coefficients (closed circles) plus or minus 1 standard error (bars) from the generalized linear models constructed using the observational dataset. Numbers above each stratum (A-F) are mean TN and TP (in milligrams per liter) and SC values (in microsiemens per centimeter at 25 degrees Celsius) associated with each stratum. Strata without a statistically significant model fit are indicated by "nm." 
Invertebrate response to nutrient concentrations in streams and rivers is widely variable among observational studies (Heino and others, 2003; Niyogi and others, 2007; Wang and others, 2007). One possible explanation for this variability may be the inherent limitations of observational data and the need to control for confounding factors. Two previous $\mathrm{TN}$-invertebrate studies of streams in the western United States (Yuan, 2010; Ouyang and others, 2018) used propensity score analysis to control for confounding factors and isolate the effects of TN on invertebrates. Yuan (2010) stratified sites into six groups as done similarly herein and showed increases (first three strata along the TN gradient) and decreases (last three strata along the TN gradient) in richness in response to increases in TN (fig. 3C in Yuan, 2010). The Ouyang and others (2018) approach was slightly different in the way confounding factors were accounted for but was still based on propensity scores (see Ouyang and others, 2018, for details). Nonetheless, results were similar between the Yuan (2010) and Ouyang and others (2018) studies along the TN gradient where richness increased at low TN concentration and decreased at higher concentrations. However, by developing regional models based on the level I ecoregions of Omernik (1987), Ouyang and others (2018) observed variability in the magnitude of effects and at what concentration positive effects changed to negative effects within the study area (Stoddard and others, 2005). Herein, effects of increased TN on richness were positive in three of six strata (fig. 3). Richness increased in response to increased $\mathrm{TN}$ at concentrations that exceeded values where effects became negative in the previous studies of Ouyang and others (2018) (0.063 mg/L) and Yuan (2010) (mean of $0.284 \mathrm{mg} / \mathrm{L}$ in stratum 4). For example, stratum E had a mean of $1.76 \mathrm{mg} / \mathrm{L}$ (app. 1, table 1.2). Four major differences between this study and Ouyang and others (2018) and Yuan (2010) are site selection (fixed compared to random), data density, geographic scale (fig. 2 herein compared to fig. 1 in Ouyang and others, 2018), and TN gradient (mean of $1.61 \mathrm{mg} / \mathrm{L}$, with a range of 0.05 to $18.00 \mathrm{mg} / \mathrm{L}$ [table 1.2 in app. 1] compared to a mean of $0.52 \mathrm{mg} / \mathrm{L}$, with a range of 0.011 to $15.63 \mathrm{mg} / \mathrm{L}$ in Yuan, 2010). These differences may have contributed to inconsistencies among results.

Ouyang and others (2018) and Yuan (2010) assumed that models of TN concentration effects captured effects of changes in other nutrient parameters (for example, TP) because they are often highly correlated. Nutrient concentrations often indirectly affect invertebrates by influencing microbial processes (Morris and Lewis, 1992), as well as periphyton biomass and composition (Chételat and others, 1999). Addition of either TN or TP has been shown to increase periphyton biomass (Francoeur, 2001) and is often site dependent (for example, Death and others, 2007). Herein, TP was included because of the study's geographic scale combined with the site dependent influence of nutrients. Effects of increased TP on richness were positive at lower concentrations and negative at higher concentrations (fig. 3, strata B and F). Sites in stratum F were mostly confined to agricultural areas of the upper Midwest; whereas, stratum B sites were distributed across most other regions (fig. 2). Overall, the distribution of sites within strata were similar for TN and TP (fig. 2), indicating that sites stratified similarly regardless of the specific RF prediction model.

\section{Invertebrate Response to Specific Conductance}

The magnitude and direction of invertebrate response to $\mathrm{SC}$ also varied substantially across strata (fig. 3). Richness decreased by 2.9 to 7.0 taxa in four of the strata (A, B, C, and F), but increased by 5.8 taxa in one stratum (D) in response to increasing SC (fig. 3). Invertebrate response to SC is well documented (Bernhardt and others, 2012; Cormier and others, 2013) and is often context dependent (Clements and Kotalik, 2016). For example, streams in regions with naturally higher SC concentrations likely harbor communities generally more tolerant to changes in SC (Kefford and others, 2012) than streams with naturally low SC (Bernhardt and others, 2012; Clements and Kotalik, 2016). Nonetheless, decreases in richness in response to increased SC were expected, which was the case in four of five modeled strata. However, effects were opposite in stratum $\mathrm{D}$ where richness increased in response to increased SC. Sites in stratum D were distributed across the United States (fig. 2), but many were clustered within the Ozarks region, an area known for limestone-dominated karsttype topography. Specific conductance values are affected by the presence of inorganic dissolved solids (for example, chloride, sulfate, calcium, magnesium), which are strongly associated with surrounding geology and regional ionic water signatures. Because SC captures ionic signatures, the ionic mixtures being measured by SC in stratum D possibly are beneficial to invertebrates. For example, the ionic mixtures in stratum D are possibly dominated by ions that contribute to the buffering capacity of water which may alter contaminant bioavailability; therefore, richness increased along the SC gradient regardless of other environmental conditions at these sites.

\section{Estimated Changes in Invertebrate Richness at Sites with Known Trends in Water Quality}

Estimated changes in invertebrate taxa richness were calculated by multiplying the appropriate GLM coefficient (representing effects of TN, TP, and SC) presented in fig. 3 by the natural log change in concentration calculated from Oelsner and others (2017). Estimated changes in invertebrate taxa richness were dependent on the direction and magnitude of trend results of each water-quality parameter (fig. 4). The GLMs mostly estimated a greater loss of invertebrate taxa as positive percent changes in TP and SC increased (fig. 4). For example, estimated taxa loss was greater when the percentage change in SC was between 76 and 100 percent than when the change was between 0 and 25 percent. Additionally, estimated gains in richness increased as greater reductions in TP and SC 


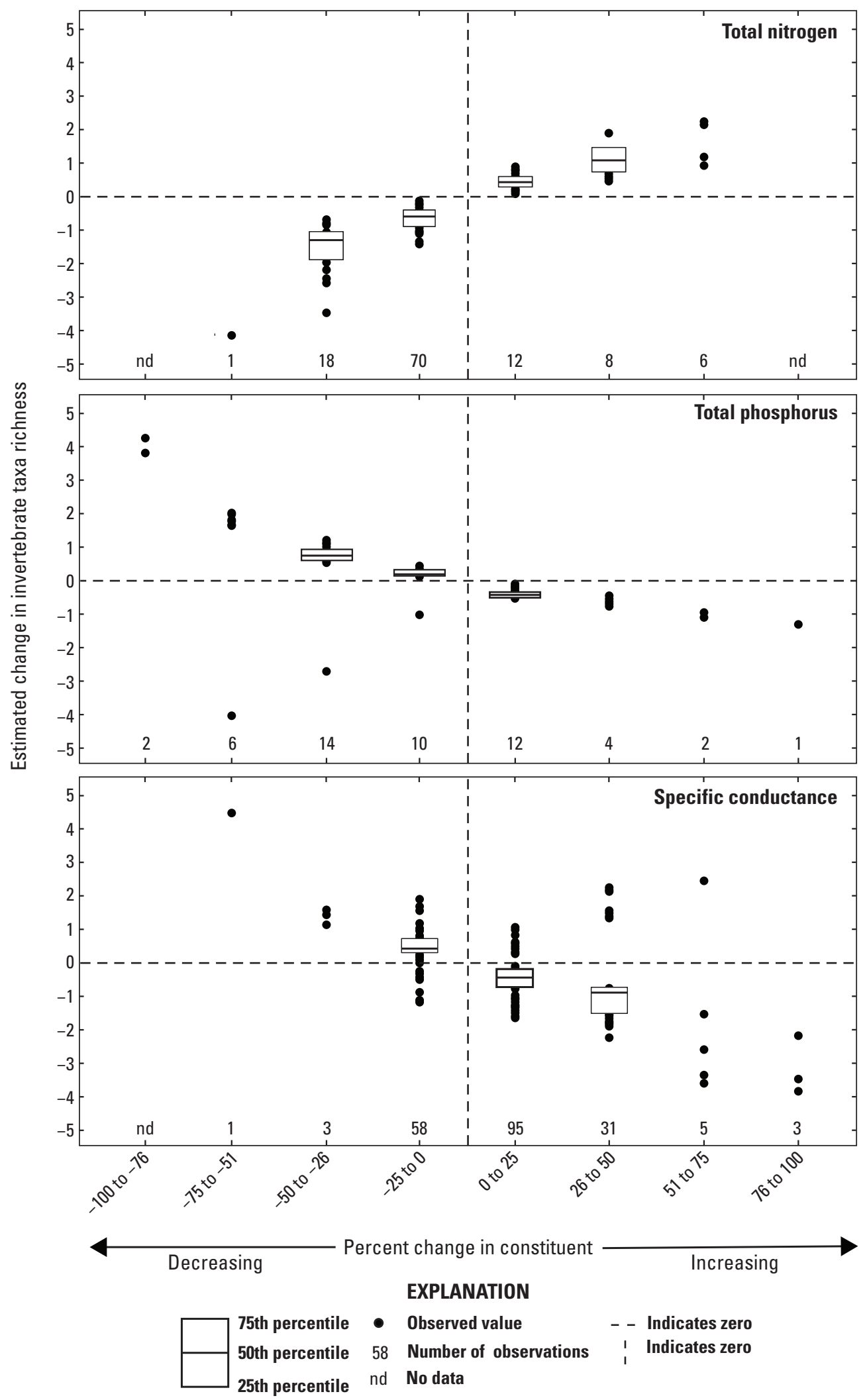

Figure 4. Graphs showing the estimated change in invertebrate taxa richness in response to percentage change in total nitrogen, total phosphorus, and specific conductance concentration at selected sites with known water-quality trends reported by 0 elsner and others (2017). Estimated change in invertebrate richness was calculated by multiplying the appropriate generalized linear model coefficient presented in figure 3 by the natural log change in concentration calculated from Oelsner and others (2017). Ranges in percentage change in concentration without data are indicated by "nd." 
occurred. In contrast, greater losses in richness were estimated as negative changes in TN increased (became more negative). For example, greater taxa loss was estimated when decreases in TN were between 51 and 75 percent than when estimated changes were between 0 and 25 percent (fig. 4). Likewise, estimated gains in richness increased as the magnitude of positive percentage changes in TN concertation increased. Overall, estimated changes in invertebrate taxa richness did not exceed plus or minus three taxa until trends in concentration were greater than plus or minus 50 percent, which only occurred on a few occasions (fig. 4).

Overall, estimated changes in invertebrate taxa richness at water-quality trend sites were much lower (most were less than two taxa; fig. 4) than predicted by the GLMs (as high as seven taxa; fig. 3) likely because changes in concentration (Oelsner and others, 2017) were often much less than a single natural $\log$ unit. The greatest estimated changes in richness in response to trends in TN, TP, and SC were mostly distributed in the eastern part of the United States compared to midwestern and western regions where most changes were less than or equal to one taxon (fig. 5). In practice, detecting changes in richness of two or three taxa will be challenging (Resh and McElravy, 1993). Nonetheless, this approach identifies where changes in richness are likely to occur in response to trends in water quality at sites where biological data are lacking. After locations are identified, efforts to validate predictions, characterize similarities among cases, and investigate causality can be targeted.

\section{Limitations}

There are several limitations to using these results to estimate invertebrate response to water-quality trends at unsampled locations. First, estimated changes in richness at water-quality trend sites were unable to be thoroughly validated because adequate data were unavailable. Ideally, each site reporting a water-quality trend would have had invertebrate samples collected each year during the same trend period, and the reported water-quality trend would be the predominant stressor influencing richness at the site. This would allow for direct comparison of estimated and observed changes in richness associated with every trend in water quality. Incorporating invertebrate data from other agencies (for example, State and Tribal agencies, and the U.S. Environmental Protection Agency and other Federal agencies) in future efforts may help increase available data for validating predictions.

Additionally, a method to compare the estimated and observed results would need to account for differences between the estimated water-quality trend and the actual water-quality conditions the biota experience in the stream. Herein, the selected WRTDS trend results are based on changes in annual flow-normalized concentration estimates that generally align with the water-quality "trend" experienced by the biota. However, because the biota experience and respond to all concentrations and streamflow conditions during a trend period, there could be a disconnect between estimated and observed changes in richness. For example, a temporary change in water quality may eliminate certain taxa causing a decrease in richness, and the change would not be evident in the WRTDS trend result but possibly detected in a time series of annual invertebrate samples. Zuellig and Carlisle (2019) describe the importance of accounting for antecedent streamflow when estimating trends in bioassessment data, and it may also be important to account for antecedent water-quality conditions. These ideas were not included in the approach herein because of the limitations associated with the lack of available concurrent invertebrate validation and continuous water-quality data associated with the data compiled herein.

Second, estimated changes in invertebrate taxa richness (fig. 3) were well below the anticipated effects of water-quality trends based on GLM results (fig. 4) and much less than a minimal detectable trend (MDT) in richness based on annual invertebrate samples as described by Gurtz and others (2013). Estimated changes in richness were less than anticipated because most reported water-quality trends captured less than a 50 percent change in concentration (fig. 4), which was often much less than the single natural log unit change needed to realize the changes illustrated in figure 3 . In a national-scale variance component study, Gurtz and others (2013) evaluated invertebrate metrics to determine how different study design choices affected the ability to detect invertebrate trends. For monitoring programs that sample annually, the MDT was 7 taxa for 20 years and 6 taxa for 30 years (Gurtz and others, 2013), where both estimates were greater than the highest estimated change herein of 4.5 taxa (fig. 4). However, the MDT aligns with estimated changes herein when the number of invertebrate samples increases to two or three samples per year. For example, the MDT decreases to 4.7 and 4.1 taxa for 2 and 3 invertebrate samples per year for 20 years and 2.9 and 2.6 taxa for 30 years (Gurtz and others, 2013). Although there a several limitations, applying this approach provides a first screening to identify where changes in invertebrate taxa richness are likely to occur and provides the necessary groundwork to improve estimation of invertebrate response to trends in water quality where biological data are lacking.

\section{Summary}

Detecting changes in water quality relative to a starting condition is often the focus of water-quality monitoring programs, and these programs have led to the development of sophisticated methods able to detect small changes in concentrations. Yet detecting a trend in water quality doesn't necessarily indicate that the change, although statistically detectable, is ecologically relevant. This report presents a possible approach to estimate changes in invertebrate taxa richness at sites with known water-quality trends but no invertebrate data. Observational data were compiled from 1,322 sites, and trend results from 259 sites were selected from a comprehensive assessment of water-quality trends in the United 
Total nitrogen
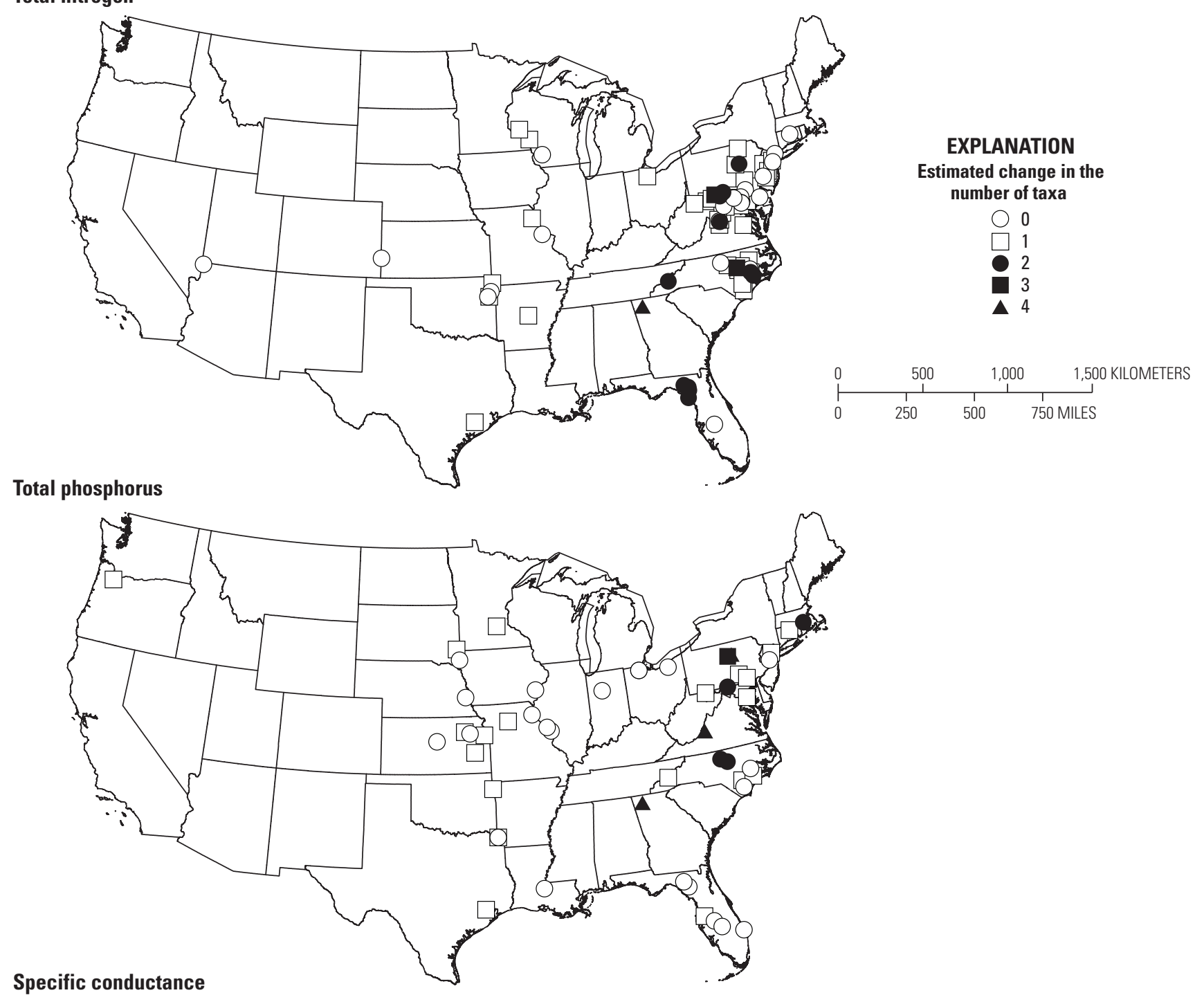

Specific conductance

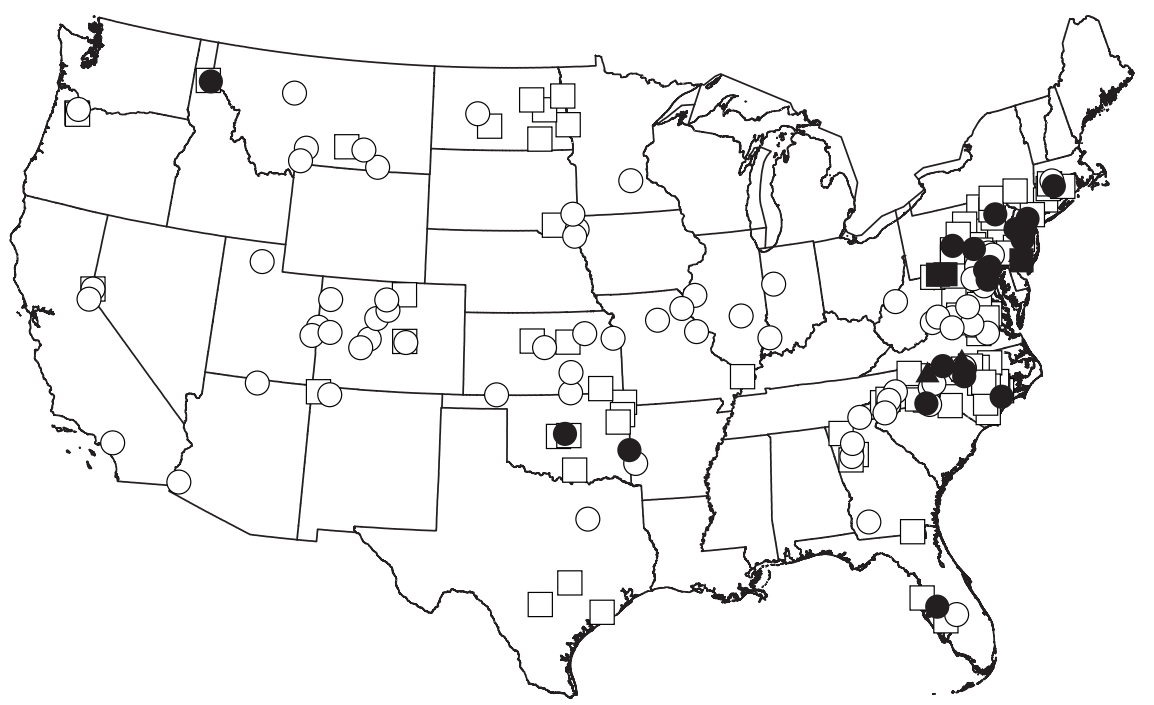

Figure 5. Maps of the United States showing estimated change in the number of taxa at selected sites with known trends in total nitrogen, total phosphorus, and specific conductance between 1992 and 2012 reported by Oelsner and others (2017). 
States. Confounding factors were controlled for by stratifying sites into groups with similar environmental characteristics along total nitrogen (TN), total phosphorus (TP), and specific conductance (SC) concentration gradients using propensity score analysis. Invertebrate response to changes in TN, TP, or SC concentration was described by constructing generalized linear models (GLMs) for each stratum and water-quality parameter. Finally, GLM results were applied to sites with known water-quality trends to estimate changes in taxa richness given reported changes in TN, TP, or SC concentration. Overall, GLMs that described invertebrate response to TN, TP, or SC were significant ( $p$ less than or equal to 0.5 ) in 10 out of 18 cases; these significant GLMs occurred at sites where changes in richness ranged between -7 and 6 taxa per log unit change in concentration. Applying the GLMs to the water-quality trend results indicates estimated changes in richness at trend sites were much lower (most were less than two taxa) than estimated by the GLMs (as high as seven taxa). This result likely occurred because the reported changes in concentration were often much less than the single natural $\log$ unit change needed to realize the invertebrate response illustrated by the GLMs. Nonetheless, regardless of limitations, this approach can be used when biological data are not available to identify sites where changes in richness are likely to occur in response to trends in water quality.

\section{Acknowledgments}

This study was funded by the U.S. Geological Survey (USGS) National Water-Quality Assessment Project of the National Water-Quality Program. The authors thank the numerous USGS ecologists, biologists, hydrologists, chemists, technicians, and others who spent countless hours in the field, laboratory, and office to make these data available. Reviews and comments by USGS colleagues Travis Schmidt, Megan Shoda, and Wesley Stone, as well as several anonymous reviewers, greatly enhanced early versions of the manuscript. Additionally, the authors are grateful for the early discussions with USGS colleagues Lori Sprague, Jennifer Murphy, Gretchen Oelsner, and James Roberts.

\section{References Cited}

Austin, P.C., 2011, An introduction to propensity score methods for reducing the effects of confounding in observational studies: Multivariate Behavioral Research, v. 46, p. 399-424. [Also available at https://doi.org/10.1080/ 00273171.2011.568786.]

Barclay, J.R., Tripp, H., Bellucci, C.J., Warner, G., and Helton, A.M., 2016, Do waterbody classifications predict water quality?: Journal of Environmental Management, v. 183, p. 1-12. [Also available at https://doi.org/10.1016/j. jenvman.2016.08.071.]
Beketov, M.A., Kefford, B.J., Schäfer, R.B., and Matthias, L., 2013, Pesticides reduce regional biodiversity of stream invertebrates: Proceedings of the National Academy of Sciences of the United States of America, v. 110, p. 11039-11043. [Also available at https://doi.org/10.1073/pnas.1305618110.]

Bernhardt, E.S., Lutz, B.D., King, R.S., Fay, J.P., Carter, C.E., Helton, A.M., Campagna, D., and Amos, J., 2012, How many mountains can we mine? Assessing the regional degradation of Central Appalachian rivers by surface coal mining: Environmental Science \& Technology, v. 46, p. 8115-8122. [Also available at https://doi.org/10.1021/es301144q.]

Chételat, J., Pick, F.R., Morin, A., and Hamilton, P.B., 1999, Periphyton biomass and community composition in rivers of different nutrient status: Canadian Journal of Fisheries and Aquatic Sciences, v. 56, p. 560-569. [Also available at https://doi.org/10.1139/f98-197.]

Clements, W.H., Kashian, D.R., Kiffney, P.M., and Zuellig, R.E., 2015, Perspectives on the context-dependency of stream community responses to contaminants: Freshwater Biology, v. 61, no. 12, p. 2162-2170. [Also available at http://doi.wiley.com/10.1111/fwb.12599.]

Clements, W.H., and Kotalik, C., 2016, Effects of major ions on natural benthic communities-An experimental assessment of the U.S. Environmental Protection Agency aquatic life benchmark for conductivity: Freshwater Science, v. 35, p. 126-138. [Also available at https://doi.org/10.1086/ 685085.]

Cohen, J., 1988, Statistical power analysis for the behavioral sciences 2nd ed.: Hillsdale, N.J., Lawrence Erlbaum Associates, $567 \mathrm{p}$.

Cormier, S.M., Suter, G.W., and Zheng, L., 2013, Derivation of a benchmark for freshwater ionic strength: Environmental Toxicology and Chemistry, v. 32, p. 263-271. [Also available at https://doi.org/10.1002/etc.2064.]

Cuffney, T.F., Gurtz, M.E., and Meador, M.R., 1993, Methods for collecting benthic invertebrate samples as part of the National Water Quality Assessment Program: U.S. Geological Survey Open File Report 93-406, 66 p. [Also available at https://pubs.er.usgs.gov/publication/ofr93406.]

Cutler, D.R., Edwards, T.C., Beard, K.H., Cutler, A., Hess, K.T., Gibson, J., and Lawler, J.J., 2007, Random forests for classification in ecology: Ecology, v. 88, p. 2783-2792. [Also available at https://doi.org/10.1890/07-0539.1.]

Death, R.G., Death, F., and Ausseil, O.M.N., 2007, Nutrient limitation of periphyton growth in tributaries and the mainstem of a central North Island river, New Zealand: New Zealand Journal of Marine and Freshwater Research, v. 41, p. 273-281. [Also available at https://doi.org/10.1080/ 00288330709509913.] 
Farmer, W.H., Murphy, J.C., Riskin, M.L., Ryberg, K.R., and Zuellig, R.E., 2017, Daily streamflow datasets used to analyze trends in streamflow at sites also analyzed for trends in water quality and ecological condition in the Nation's rivers and streams: U.S. Geological Survey data release, accessed May 6, 2021, at https://doi.org/10.5066/F7D798JN.

Fitzpatrick, F.A., Waite, I.R., D’Arconte, P.J., Meador, M.R., Maupin, M.A., and Gurtz, M.E., 1998, Revised methods for characterizing stream habitat in the National Water Quality Assessment Program: U.S. Geological Survey WaterResources Investigations Report 98-4052, 67 p. [Also available at https://pubs.usgs.gov/wri/wri984052/.]

Francoeur, S.N., 2001, Meta-analysis of lotic nutrient amendment experiments-Detection and quantifying subtle responses: Journal of the North American Benthological Society, v. 20, no. 3, p. 358-368. [Also available at https://www.jstor.org/stable/1468034.]

Gilliom, R.J., Alley, W.M., and Gurtz, M.E., 1995, Design of the National Water Quality Assessment ProgramOccurrence and distribution of water-quality conditions: U.S. Geological Survey Circular 1112, 33 p. [Also available at https://pubs.er.usgs.gov/publication/cir1112.]

Gurtz, M.E., Van Sickle, J., Carlisle, D.M., and Paulsen, S.G., 2013, Design tradeoffs for trend assessment in aquatic biological monitoring programs: U.S. Geological Survey Open-File Report 2013-1222, 15 p. plus 1 app., accessed May 6, 2021, at https://doi.org/10.3133/ofr20131222.

Heino, J., Muotka, T., and Paavola, R., 2003, Determinants of macroinvertebrate diversity in headwater streamsRegional and local influences: Journal of Animal Ecology, v. 72, p. 425-434. [Also available at https://doi.org/10.1046/ j.1365-2656.2003.00711.x.]

Hirsch, R.M., Archfield, S.A., and De Cicco, L.A., 2015, A bootstrap method for estimating uncertainty of water quality trends: Environmental Modelling \& Software, v. 73, p. 148-166. [Also available at https://doi.org/10.1016/j. envsoft.2015.07.017.]

Hirsch, R.M., and De Cicco, L.A., 2015, User guide to exploration and graphics for RivEr Trends (EGRET) and dataRetrieval—R Packages for hydrologic data (version 2.0, February 2015): U.S. Geological Survey Techniques and Methods 4-A10, 93 p., accessed May 6, 2021, at https://doi.org/10.3133/tm4A10.

Hirsch, R.M., Douglas, D.L., and Archfield, S.A., 2010, Weighted Regressions on Time, Discharge, and Season (WRTDS), with application to Chesapeake Bay River inputs: Journal of the American Water Resources Association, v. 46, p. 857-880. [Also available at https://doi.org/10.1111/j.1752-1688.2010.00482.x.]
Kefford, B.J., Hickey, G.L., Gasith, A., Ben-David, E., Dunlop, J.E., Palmer, C.G., Allan, K., Choy, S.C., and Piscart, C., 2012, Global scale variation in the salinity sensitivity of riverine macroinvertebrates-Eastern Australia, France, Israel and South Africa: PLoS One, v. 7, p. 1-12. [Also available at https://doi.org/10.1371/ journal.pone.0035224.]

Millward, R.N., and Klerks, P.L., 2002, Contaminantadaptation and community tolerance in ecological risk assessment-Introduction: Human and Ecological Risk Assessment, v. 8, p. 921-932. [Also available at https://doi.org/10.1080/1080-700291905747.]

Morris, D.P., and Lewis, W.M., Jr., 1992, Nutrient limitation of bacterioplankton growth in Lake Dillon, Colorado: Limnology and Oceanography, v. 37, p. 1179-1192. [Also available at https://doi.org/10.4319/lo.1992.37.6.1179.]

Moulton, S.R., II, Carter, J.L., Grotheer, S.A., Cuffney, T.F., and Short, T.M., 2000, Methods of analysis by the U.S. Geological Survey National Water Quality Laboratory — Processing, taxonomy, and quality control of benthic macroinvertebrate samples: U.S. Geological Survey Open File Report 00-212, 49 p. [Also available at https://nwql.usgs.gov/OFR-00-212.shtml.]

Moulton, S.R., Kennen, J.G., Goldstein, R.M., and Hambrook, J.A., 2002, Revised protocols for sampling algal, invertebrate, and fish communities as part of the National WaterQuality Assessment Program: U.S. Geological Survey Open File Report 02-150, 75 p. [Also available at https://pubs. usgs.gov/of/2002/ofr-02-150/pdf/ofr02-150.pdf.]

Murphy, J.C., and Sprague, L.A., 2019, Water-quality trends in US rivers-Exploring effects from streamflow trends and changes in watershed management: The Science of the Total Environment, v. 656, p. 645-658. [Also available at https://doi.org/10.1016/j.scitotenv.2018.11.255.]

Myers, D.N., and Ludtke, A.S., 2017, Progress and lessons learned from water-quality monitoring networks, chap. 2 of Satinder, A., ed., Chemistry and water-The science behind sustaining the world's most crucial resource: Amsterdam, Elsevier, p. 23-120. [Also available at https:// doi.org/10.1016/B978-0-12-809330-6.00002-7.]

Niyogi, D.K., Koren, M., Arbuckle, C.J., and Townsend, C.R., 2007, Stream communities along a catchment land-use gradient - Subsidy-stress responses to pastoral development: Environmental Management, v. 39, p. 213-225. [Also available at https://doi.org/10.1007/s00267-005-0310-3.] 
Oelsner, G.P., Sprague, L.A., Murphy, J.C., Zuellig, R.E., Johnson, H.M., Ryberg, K.R., Falcone, J.A., Stets, E.G., Vecchia, A.V., Riskin, M.L., De Cicco, L.A., Mills, T.J., and Farmer, W.H., 2017, Water-quality trends in the Nation's rivers and streams, 1972-2012-Data preparation, statistical methods, and trend results (ver. 2.0, October 2017): U.S. Geological Survey Scientific Investigations Report 2017-5006, 136 p., accessed May 6, 2021, at https://doi.org/ $10.3133 / \operatorname{sir} 20175006$.

Omernik, J.M., 1987, Ecoregions of the conterminous United States: Annals of the Association of American Geographers, v. 77, p. 118-125. [Also available at https://doi.org/10.1111/ j.1467-8306.1987.tb00149.x.]

Ouyang, Z., Qian, S.S., Beker, R., and Chen, J., 2018, The effects of nutrients on stream invertebrates - A regional estimation by generalized propensity score: Ecological Processes, v. 7, no. 21, 13 p., accessed February 2, 2019, at https://doi.org/10.1186/s13717-018-0132-x.

Pacheco, M.A.W., Mcintyre, D.O., and Linton, T.K., 2005, Integrating chemical and biological criteria: Environmental Toxicology and Chemistry, v. 24, p. 2983-2991. [Also available at https://doi.org/10.1897/04-624R.1.]

Resh, V.H., and McElravy, E.P., 1993, Contemporary quantitative approaches to biomonitoring using benthic macroinvertebrates, in Rosenberg, D.M., and Resh, V.H., eds., Freshwater biomonitoring and benthic macroinvertebrates: New York, Chapman \& Hall, p. 159-194.

Rosenbaum, P.R., and Rubin, D.B., 1984, Reducing bias in observational studies using subclassification on the propensity score: Journal of the American Statistical Association, v. 79, no. 387, p. 516-524. [Also available at https://doi.org/ 10.1080/01621459.1984.10478078.]

Runkel, R.L., Kimball, B.A., Nimick, D.A., and Walton-Day, K., 2016, Effects of flow regime on metal concentrations and the attainment of water quality standards in a remediated stream reach, Butte, Montana: Environmental Science \& Technology, v. 50, p. 12641-12649. [Also available at https://doi.org/10.1021/acs.est.6b03190.]

Ryberg, K.R., and Vecchia, A.V., 2013, seawaveQ_-An R package providing a model and utilities for analyzing trends in chemical concentrations in streams with a seasonal wave (seawave) and adjustment for streamflow (Q) and other ancillary variables: U.S. Geological Survey OpenFile Report 2013-1255, 13 p., with 3 appendixes, accessed May 6, 2021, at https://doi.org/10.3133/ofr20131255.

Schmidt, T.S., Clements, W.H., Zuellig, R.E., Mitchell, K.A., Church, S.E., Wanty, R.B., San Juan, C.A., Adams, M., and Lamothe, P.J., 2011, Critical tissue residue approach linking accumulated metals in aquatic insects to population and community-level effects: Environmental Science \& Technology, v. 45, p. 7004-7010. [Also available at https://doi.org/10.1021/es200215s.]
Schmidt, T.S., Van Metre, P.C., and Carlisle, D.M., 2019, Linking the agricultural landscape of the Midwest to stream health with structure equation modeling: Environmental Science \& Technology, v. 53, p. 452-462. [Also available at https://doi.org/10.1021/acs.est.8b04381.]

Shoda, M.E., Sprague, L.A., Murphy, J.C., and Riskin, M.L., 2019, Water-quality trends in U.S. rivers, 2002 to 2012 Relations to levels of concern: The Science of the Total Environment, v. 650, p. 2314-2324. [Also available at https://doi.org/10.1016/j.scitotenv.2018.09.377.]

Stoddard, J.L., Peck, D.V., Olsen, A.R., Larsen, D.P., Van Sickle, J., Hawkins, C.P., Hughes, R.M., Whittier, T.R., Lomnicky, G., Herlihy, A.T., Kaufmann, P.R., Peterson, S.A., Ringold, P.L., Paulsen, S.G., and Blair, R., 2005, Environmental monitoring and assessment (EMAP) West-Western streams and rivers statistical summary: Washington, D.C., U.S. Environmental Protection Agency, Office of Research and Development, EPA 620/R-05/006, 1,762 p., accessed May 6, 2021, at https://archive.epa.gov/ emap/archive-emap/web/html/wstream.html.

The R Foundation, 2014, The R Project for statistical computing: The R Foundation website, accessed May 6, 2021, at http://www.R-project.org.

U.S. Geological Survey [USGS], 2020, BioData-Aquatic Bioassessment Data for the Nation, U.S. Geological Survey website, accessed August 10, 2018, at https://doi.org/ 10.5066/f77w698b.

U.S. Geological Survey, [USGS], variously dated, National Field Manual for the Collection of Water-Quality Data (NFM): U.S. Geological Survey Techniques and Methods, book 9, chaps. A1-A10, accessed January 5, 2019, at https://pubs.water.usgs.gov/twri9A.

Wang, L., Robertson, D.M., and Garrison, P.J., 2007, Linkages between nutrients and assemblages of macroinvertebrates and fish in wadeable streams - Implication to nutrient criteria development: Environmental Management, v. 39, p. 194-212. [Also available at https://doi.org/10.1007/ s00267-006-0135-8.]

Wieczorek, M.E., Jackson, S.E., and Schwarz, G.E., 2018, Select attributes for NHDPlus version 2.1 reach catchments and modified network routed upstream watersheds for the conterminous United States (ver. 2.0, November 2019): U.S. Geological Survey data release, accessed February 2, 2020, at https://doi.org/10.5066/F7765D7V.

Yuan, L.L., 2010, Estimating the effects of excess nutrients on stream invertebrates from observational data: Ecological Applications, v. 20, p. 110-125. [Also available at https://doi.org/10.1890/08-1750.1.] 
Yuan, L.L., Pollard, A.I., and Carlisle, D.M., 2009, Using propensity scores to estimate the effects of insecticides on stream invertebrates from observational data: Environmental Toxicology and Chemistry, v. 28, p. 1518-1527. [Also available at https://doi.org/10.1897/08-551.1.]

Zuellig, R.E., and Carlisle, D.M., 2021, Datasets for estimating invertebrate response to changes in total nitrogen, total phosphorus, and specific conductance at sites where invertebrate data are unavailable: U.S. Geological Survey data release, https://doi.org/10.5066/P9SMFACO.

Zuellig, R.E., and Carlisle, D.M., 2019, Effects of antecedent streamflow and sample timing on trend assessment of fish, invertebrate, and diatom communities: Journal of the American Water Resources Association, v. 55, p. 102-115. [Also available at https://doi.org/10.1111/1752-1688.12706.]

Zuellig, R.E., and Schmidt, T.S., 2012, Characterizing invertebrate traits in wadeable streams of the contiguous USDifferences among ecoregions and land uses: Freshwater Science, v. 31, p. 1042-1056. [Also available at https://doi. org/10.1899/11-150.1.] 


\section{Appendix 1. Covariate Definitions and Data Characteristics for each Propensity Score-Based Stratum}

Table 1.1. Covariates used in each random forests (RF) model to define propensity-score based stratum. Total nitrogen (TN), total phosphorus (TP), and specific conductance (SC) in the RF column identifies which covariates were used in the TN, TP, and SC RF models.

$[\mu \mathrm{S} / \mathrm{cm}$, microsiemens per centimeter at 25 degrees Celsius; mg/L, milligrams per liter; cm/yr, centimeters per year; km, kilometer; PRISM, ParameterElevation Regressions on Independent Slopes Model; m, meter; mm, millimeter; NPDES, National Pollutant Discharge Elimination System; $\mathrm{km}^{2}$, square kilometer; kg, kilogram]

\begin{tabular}{|c|c|c|}
\hline Code & Covariate definition and units & RF \\
\hline \multicolumn{3}{|c|}{ Chemistry } \\
\hline $\mathrm{SC}$ & Specific conductance $(\mu \mathrm{S} / \mathrm{cm})$ measured within 60 days of invertebrate sample. & TN, TP \\
\hline $\mathrm{TN}$ & Total nitrogen $(\mathrm{mg} / \mathrm{L})$ measured within 60 days of invertebrate sample. & $\mathrm{SC}, \mathrm{TP}$ \\
\hline TP & Total phosphorus $(\mathrm{mg} / \mathrm{L})$ measured within 60 days of invertebrate sample. & $\mathrm{SC}, \mathrm{TN}$ \\
\hline \multicolumn{3}{|c|}{ Climate } \\
\hline pmpe & Mean annual precipitation minus mean annual evapotranspiration ( $\mathrm{cm} / \mathrm{yr})$. & SC \\
\hline FST32F_BASIN & $\begin{array}{l}\text { Watershed mean of average day of the year of first freeze, derived from } 30 \text { years of records } \\
\text { (1961-1990) and using a 2-km PRISM. For example, value of } 300 \text { is the 300th day of the } \\
\text { year (October 27). }\end{array}$ & $\mathrm{SC}, \mathrm{TN}, \mathrm{TP}$ \\
\hline LST32F_BASIN & $\begin{array}{l}\text { Watershed average of mean day of the year of last freeze, derived from } 30 \text { years of records } \\
\text { (1961-1990) and using a 2-km PRISM. For example, value of } 100 \text { is the 100th day of the } \\
\text { year (April 10). }\end{array}$ & $\mathrm{TP}$ \\
\hline PPTAVG_BASIN & $\begin{array}{l}\text { Mean annual precipitation }(\mathrm{cm} / \mathrm{yr}) \text { for the watershed, from } 800 \text {-m PRISM data derived from } \\
30 \text { years of records }(1981-2010) \text {. }\end{array}$ & $\mathrm{SC}, \mathrm{TN}, \mathrm{TP}$ \\
\hline WD_FEB_BASIN & $\begin{array}{l}\text { Watershed average of annual number of days of measurable precipitation in February, derived } \\
\text { from } 30 \text { years of records (1961-1990), 2.3-km PRISM. }\end{array}$ & $\mathrm{SC}$ \\
\hline \multicolumn{3}{|c|}{ Soils } \\
\hline CONTACT & $\begin{array}{l}\text { Subsurface flow contact time index. The subsurface contact time index estimates the number } \\
\text { of days that infiltrated water resides in the saturated subsurface zone of the watershed before } \\
\text { discharging into the stream. }\end{array}$ & $\mathrm{SC}$ \\
\hline HGC & $\begin{array}{l}\text { Percentage of soils in hydrologic group C in the watershed. Hydrologic group C soils have slow } \\
\text { soil infiltration rates. The soil profiles include layers impeding downward movement of water } \\
\text { and, typically, have moderately fine or fine texture. }\end{array}$ & $\mathrm{TN}$ \\
\hline NO10AVE & $\begin{array}{l}\text { Average value of watershed percent by weight of soil material less than } 3 \text { inches in size and } \\
\text { passing a No. } 10 \text { sieve }(2 \mathrm{~mm}) \text {. }\end{array}$ & $\mathrm{TP}$ \\
\hline NO200AVE & $\begin{array}{l}\text { Average value of watershed percent by weight of soil material less than } 3 \text { inches in size and } \\
\text { passing a No. } 200 \text { sieve }(0.074 \mathrm{~mm}) \text {. }\end{array}$ & $\mathrm{TP}$ \\
\hline RECHARGE & Aquifer recharge time in number of days. & $\mathrm{SC}$ \\
\hline SGEO35 & $\begin{array}{l}\text { Percentage surficial geology class } 35 \text { in the watershed. Shaley or sandy ground; on mixed } \\
\text { sandstone and shale formations; where shaley, contains considerable swelling clay in the } \\
\text { watershed. }\end{array}$ & $\mathrm{SC}$ \\
\hline SILTAVE & Average value of watershed percent by weight of silt. & $\mathrm{TP}$ \\
\hline S_pct & Average percent silica concentration of watershed lithology. & $\mathrm{SC}$ \\
\hline
\end{tabular}


Table 1.1. Covariates used in each random forests (RF) model to define propensity-score based stratum. Total nitrogen (TN), total phosphorus (TP), and specific conductance (SC) in the RF column identifies which covariates were used in the TN, TP, and SC RF models.-Continued

$[\mu \mathrm{S} / \mathrm{cm}$, microsiemens per centimeter at 25 degrees Celsius; mg/L, milligrams per liter; cm/yr, centimeters per year; km, kilometer; PRISM, ParameterElevation Regressions on Independent Slopes Model; m, meter; mm, millimeter; NPDES, National Pollutant Discharge Elimination System; km² square kilometer; kg, kilogram]

\begin{tabular}{|c|c|c|}
\hline Code & Covariate definition and units & $\mathbf{R F}$ \\
\hline \multicolumn{3}{|c|}{ Land use and land cover } \\
\hline agproduction_1982 & Percent of watershed in crop, pasture/hay, and grazing potential in 1982. & $\mathrm{TN}$ \\
\hline TOT_NPDES_MAJ_DENS & $\begin{array}{l}\text { Density of 2006-era major NPDES sites in watershed, number per } 100 \mathrm{~km}^{2} \text {. These include other } \\
\text { major dischargers in addition to waste water treatment plants, for example industrial plants, } \\
\text { paper mills, and so on. }\end{array}$ & $\mathrm{TP}$ \\
\hline TOT_NLCD11_42_RIP50 & Riparian 50-m flow distance buffer percent Evergreen Forest (class 42). & $\mathrm{SC}$ \\
\hline TOT_NWALT12_43 & Watershed percent Crops (class 43). & $\mathrm{TN}$ \\
\hline TOT_NWALT12_21 & $\begin{array}{l}\text { Watershed percent Developed, Transportation. Major roads, rail and airports, along with their } \\
\text { associated facilities (class 21). }\end{array}$ & $\mathrm{TN}$ \\
\hline SLOPE_PCT_30M & $\begin{array}{l}\text { Mean watershed slope, percent. Derived from 30-m National Hydrography Dataset (NHDPlus } \\
\text { V2.1). }\end{array}$ & $\mathrm{SC}, \mathrm{TN}, \mathrm{TP}$ \\
\hline
\end{tabular}

Table 1.2. Mean, minimum ( $\min )$, and maximum $(\max )$ values for each propensity score-based stratum.

[TN, total nitrogen; mg/L, milligrams per liter; TP, total phosphorus; SC, specific conductance; $\mu \mathrm{S} / \mathrm{cm}$, microsiemens per centimeter at 25 degrees Celsius]

\begin{tabular}{|c|c|c|c|c|c|c|c|c|c|}
\hline \multirow[t]{2}{*}{ Stratum } & \multicolumn{3}{|c|}{$\begin{array}{c}\mathrm{TN} \\
(\mathrm{mg} / \mathrm{L})\end{array}$} & \multicolumn{3}{|c|}{$\begin{array}{c}\mathrm{TP} \\
(\mathrm{mg} / \mathrm{L})\end{array}$} & \multicolumn{3}{|c|}{$\begin{array}{c}S C \\
(\mu S / c m)\end{array}$} \\
\hline & mean & $\min$ & $\max$ & mean & $\min$ & $\max$ & mean & $\min$ & $\max$ \\
\hline B & 0.45 & 0.15 & 0.83 & 0.021 & 0.004 & 0.053 & 127 & 44 & 250 \\
\hline $\mathrm{C}$ & 0.69 & 0.16 & 1.3 & 0.035 & 0.004 & 0.072 & 217 & 53 & 390 \\
\hline $\mathrm{E}$ & 1.76 & 0.45 & 4.1 & 0.105 & 0.01 & 0.25 & 542 & 282 & 918 \\
\hline $\mathrm{F}$ & 5.52 & 1.10 & 18 & 0.425 & 0.01 & 3.4 & 957 & 155 & 3,420 \\
\hline
\end{tabular}


Table 1.3. Mean, minimum ( $\min )$, and maximum ( $\max$ ) covariate values among propensity score-based stratum (A-F) for the total nitrogen random forests model. Covariate definitions are provided in table 1.1.

[ $\mathrm{\mu S} / \mathrm{cm}$, microsiemens per centimeter at $25^{\circ}$ degrees Celsius; $\mathrm{mg} / \mathrm{L}$, milligrams per liter; $\%$, percent; $\mathrm{kg} / \mathrm{km}^{2}$, kilograms per square kilometer; km², square kilometer; $\mathrm{cm} / \mathrm{year}$, centimeters per year]

\begin{tabular}{|c|c|c|c|c|c|c|c|c|c|c|c|c|c|c|c|c|c|c|}
\hline \multirow{2}{*}{ Covariate } & \multicolumn{3}{|c|}{ A } & \multicolumn{3}{|c|}{ B } & \multicolumn{3}{|c|}{ C } & \multicolumn{3}{|c|}{ D } & \multicolumn{3}{|c|}{$\mathbf{E}$} & \multicolumn{3}{|c|}{$\mathbf{F}$} \\
\hline & mean & $\min$ & $\max$ & mean & $\min$ & $\max$ & mean & $\min$ & $\max$ & mean & $\min$ & $\max$ & mean & $\min$ & $\max$ & mean & $\min$ & $\max$ \\
\hline $\mathrm{SC}(\mu \mathrm{S} / \mathrm{cm})$ & 148 & 8 & 687 & 291 & 16 & 3,420 & 272 & 34 & 1,750 & 469 & 31 & 2,605 & 506 & 61 & 2,700 & 614 & 44 & 2,210 \\
\hline $\mathrm{TP}(\mathrm{mg} / \mathrm{L})$ & 0.016 & 0 & 0.118 & 0.03 & 0.01 & 0.147 & 0.053 & 0 & 0.227 & 0.081 & 0 & 0.49 & 0.146 & 0.01 & 1.048 & 0.335 & 0.01 & 3.4 \\
\hline $\begin{array}{l}\text { TOT_NWALT12_43 } \\
(\%)\end{array}$ & 0.42 & 0 & 9 & 2.16 & 0 & 30.57 & 5.09 & 0 & 62.66 & 14.56 & 0 & 97.47 & 37.18 & 0 & 96.96 & 54.71 & 0 & 99.14 \\
\hline $\begin{array}{l}\text { agproduction_1982 } \\
\quad(\%)\end{array}$ & 4.33 & 0 & 31.65 & 12.96 & 0 & 55.71 & 19.53 & 0 & 78.87 & 30.3 & 0 & 98.12 & 53.56 & 0 & 98.2 & 69.29 & 0.12 & 99.15 \\
\hline TOT_N97 $\left(\mathrm{kg} / \mathrm{km}^{2}\right)$ & 376 & 0 & 3,316 & 1130 & 0.49 & 6,698 & 1,904 & 9 & 8,488 & 2,967 & 35 & 9,538 & 5,263 & 84 & 13,680 & 7,448 & 649 & 16,536 \\
\hline $\begin{array}{l}\text { TOT_NWALT12_21 } \\
(\%)\end{array}$ & 0.26 & 0 & 3.23 & 0.85 & 0 & 9 & 2.01 & 0 & 10.27 & 2.62 & 0 & 16.23 & 1.56 & 0 & 13.59 & 1.62 & 0 & 37.74 \\
\hline $\begin{array}{l}\text { agproduction_2002 } \\
\quad(\%)\end{array}$ & 4.34 & 0 & 34.07 & 12.34 & 0 & 57.98 & 17.6 & 0 & 74.47 & 27.28 & 0 & 98.13 & 50.19 & 0 & 98.05 & 66.73 & 0.02 & 99.14 \\
\hline $\begin{array}{l}\text { TOT_NLCD11_82 } \\
\text { RIP50 (\%) }\end{array}$ & 0.36 & 0 & 11.18 & 1.53 & 0 & 35.24 & 2.75 & 0 & 40.68 & 8.17 & 0 & 91.65 & 24.63 & 0 & 90.1 & 39.79 & 0 & 89.06 \\
\hline HGC (\%) & 30.17 & 0 & 97.27 & 33.25 & 0 & 99.4 & 34.04 & 0 & 96.51 & 32.82 & 0 & 100 & 32.1 & 0 & 84.96 & 20.42 & 0 & 93.36 \\
\hline $\begin{array}{l}\text { DRAIN_SQKM } \\
\qquad\left(\mathrm{km}^{2}\right)\end{array}$ & 1,140 & 6.16 & 27,248 & 1,714 & 9.08 & 41,576 & 1,186 & 4.65 & 30,343 & 1,821 & 5.66 & 139,505 & 703 & 0.26 & 46,244 & 1,088 & 4.78 & 34,224 \\
\hline $\begin{array}{l}\text { SLOPE_PCT_30M } \\
(\%)\end{array}$ & 25.94 & 2.43 & 77.78 & 13.5 & 0.63 & 63.52 & 8.55 & 0 & 49.93 & 6.14 & 0.04 & 47.1 & 5.09 & 0.01 & 41.24 & 3.43 & 0.05 & 25.21 \\
\hline $\begin{array}{c}\text { FST32F_BASIN } \\
\text { (day-of-year) }\end{array}$ & 269 & 215 & 314 & 281 & 232 & 326 & 292 & 229 & 368 & 291 & 244 & 345 & 287 & 245 & 367 & 286 & 260 & 345 \\
\hline $\begin{array}{l}\text { PPTAVG_BASIN } \\
\text { (cm/year) }\end{array}$ & 121 & 35 & 355 & 111 & 30 & 255 & 117 & 39 & 184 & 106 & 25 & 166 & 100 & 22 & 159 & 92 & 19 & 164 \\
\hline
\end{tabular}


Table 1.4. Mean, minimum (min), and maximum (max) covariate values among propensity score-based stratum (A-F) for the total phosphorus random forests model. Covariate definitions are provided in table 1.1.

[ $\mu \mathrm{S} / \mathrm{cm}$, microsiemens per centimeter at 25 degrees Celsius; $\mathrm{mg} / \mathrm{L}$, milligrams per liter; \%, percent; $\# / 100 \mathrm{~km}^{2}$, number per square kilometer; km² square kilometer; $\mathrm{cm} / \mathrm{year}$, centimeters per year]

\begin{tabular}{|c|c|c|c|c|c|c|c|c|c|c|c|c|c|c|c|c|c|c|}
\hline \multirow{2}{*}{ Covariate } & \multicolumn{3}{|c|}{ A } & \multicolumn{3}{|c|}{ B } & \multicolumn{4}{|c|}{ C } & \multicolumn{2}{|r|}{ D } & \multirow[b]{2}{*}{ mean } & \multicolumn{3}{|c|}{$E$} & \multicolumn{2}{|c|}{$\mathbf{F}$} \\
\hline & mean & $\min$ & $\max$ & mean & $\min$ & $\max$ & mean & $\min$ & $\max$ & mean & $\min$ & $\max$ & & $\min$ & $\max$ & mean & $\min$ & $\max$ \\
\hline $\mathrm{SC}(\mu \mathrm{S} / \mathrm{cm})$ & 158 & 8 & 1,040 & 274 & 20 & 3,420 & 309 & 16 & 2,740 & 422 & 32 & 2,700 & 535 & 36 & 2,605 & 602 & 79 & 2,080 \\
\hline $\mathrm{TN}(\mathrm{mg} / \mathrm{L})$ & 0.29 & 0.05 & 0.89 & 0.57 & 0.07 & 2.8 & 1.06 & 0.11 & 6.8 & 1.51 & 0.16 & 8.8 & 2.41 & 0.15 & 17.49 & 3.95 & 0.34 & 18 \\
\hline NO200AVE (\%) & 41.02 & 15.8 & 71.28 & 47.29 & 14.6 & 78.65 & 51.66 & 17.3 & 86.31 & 55.13 & 17.3 & 86.62 & 63.9 & 9.79 & 94.3 & 73.09 & 8.04 & 97.38 \\
\hline $\begin{array}{l}\text { TOT_NPDES_MAJ_DENS } \\
\left(\# / 100 \mathrm{~km}^{2}\right)\end{array}$ & 0.01 & 0 & 0.85 & 0.06 & 0 & 2.44 & 0.09 & 0 & 2.34 & 0.09 & 0 & 3.15 & 0.15 & 0 & 6.5 & 0.34 & 0 & 7.33 \\
\hline NO10AVE (\%) & 64.22 & 33 & 96.7 & 72.56 & 31.2 & 97.08 & 79.04 & 42.7 & 97.99 & 82.13 & 42.7 & 97.57 & 87.73 & 49.1 & 99.9 & 91.61 & 48.8 & 100 \\
\hline SILTAVE (\%) & 43.22 & 18 & 60.93 & 40.76 & 15 & 62.93 & 39.46 & 13.8 & 67.16 & 41.03 & 13.8 & 66.53 & 46.47 & 5.37 & 72.27 & 51.85 & 4.34 & 73.71 \\
\hline LST32F_BASIN (day-of-year) & 134 & 81 & 208 & 121 & 68 & 202 & 114 & 73 & 179 & 116 & 69 & 177 & 118 & 60 & 190 & 115 & 27 & 176 \\
\hline DRAIN_SQKM $\left(\mathrm{km}^{2}\right)$ & 617 & 4.65 & 10,186 & 1,316 & 5.66 & 29,742 & 1,182 & 2.09 & 41,576 & 1,139 & 0.26 & 30343 & 1,689 & 4.78 & 139,505 & 1,585 & 5.32 & 34,224 \\
\hline SLOPE_PCT_30M (\%) & 21.9 & 2.4 & 77.78 & 13.12 & 0.11 & 51.79 & 9.26 & 0.01 & 63.52 & 7.96 & 0.07 & 49.93 & 5.18 & 0.05 & 39.43 & 4.8 & 0 & 35.82 \\
\hline FST32F_BASIN (day-of-year) & 274 & 215 & 314 & 284 & 221 & 323 & 289 & 233 & 326 & 287 & 240 & 323 & 285 & 235 & 331 & 287 & 244 & 368 \\
\hline PPTAVG_BASIN (cm/year) & 128 & 62 & 355 & 118 & 34 & 234 & 111 & 36 & 183 & 105 & 22 & 168 & 96 & 22 & 163 & 90 & 19 & 166 \\
\hline
\end{tabular}


Table 1.5. Mean, minimum ( $\mathrm{min})$, and maximum (max) covariate values among propensity score-based stratum (A-F) for the specific conductance random forests model. Covariate definitions are provided in table 1.1.

[mg/L, milligrams per liter; $\mathrm{cm} / \mathrm{yr}$, centimeters per year; \%, percent; $\mathrm{km}^{2}$, square kilometer; $\mathrm{cm}$, centimeter]

\begin{tabular}{|c|c|c|c|c|c|c|c|c|c|c|c|c|c|c|c|c|c|c|}
\hline \multirow{2}{*}{ Covariate } & \multicolumn{3}{|c|}{ A } & \multicolumn{3}{|c|}{ B } & \multicolumn{4}{|c|}{ C } & \multicolumn{2}{|c|}{ D } & \multirow[b]{2}{*}{ mean } & \multicolumn{2}{|c|}{ E } & \multicolumn{3}{|c|}{$\mathbf{F}$} \\
\hline & mean & $\min$ & $\max$ & mean & $\min$ & $\max$ & mean & $\min$ & $\max$ & mean & $\min$ & $\max$ & & $\min$ & $\max$ & mean & $\min$ & $\max$ \\
\hline $\mathrm{TN}(\mathrm{mg} / \mathrm{L})$ & 0.52 & 0.05 & 2 & 0.8 & 0.06 & 4.95 & 1.27 & 0.05 & 11.7 & 1.23 & 0.07 & 12 & 2.85 & 0.21 & 16 & 3.17 & 0.24 & 18 \\
\hline $\mathrm{TP}(\mathrm{mg} / \mathrm{L})$ & 0.03 & 0 & 0.25 & 0.053 & 0 & 1.048 & 0.07 & 0 & 0.88 & 0.112 & 0 & 1.83 & 0.189 & 0 & 3.4 & 0.217 & 0.01 & 2.5 \\
\hline pmpe (cm/yr) & 687 & 197 & 2,983 & 523 & 187 & 1,754 & 464 & -184 & 836 & 323 & -415 & 671 & 178 & -522 & 646 & 139 & -644 & 602 \\
\hline SGEO35 (\%) & 0 & 0 & 0 & 0 & 0 & 0 & 0.01 & 0 & 2.66 & 0.03 & 0 & 5.8 & 0.54 & 0 & 92.07 & 2.81 & 0 & 100 \\
\hline $\begin{array}{l}\text { WD_FEB_BASIN (number } \\
\text { of days) }\end{array}$ & 10.73 & 6.75 & 22.71 & 10.19 & 5.62 & 19.05 & 9.74 & 3.78 & 17.01 & 8.05 & 3 & 16.56 & 6.34 & 2.88 & 11.93 & 6.62 & 3 & 14 \\
\hline RECHARGE (number of days) & 392 & 93 & 1,675 & 271 & 92 & 1,096 & 235 & 15 & 525 & 176 & 8 & 479 & 90 & 4 & 361 & 93 & 5 & 360 \\
\hline CONTACT (number of days) & 185 & 1 & 3,079 & 601 & 4 & 20,454 & 590 & 6 & 12,386 & 495 & 2 & 10,368 & 730 & 8 & 8,263 & 930 & 4 & 10,272 \\
\hline TOT_NLCD11_42_RIP50 (\%) & 25.18 & 0 & 100 & 14.44 & 0 & 91.62 & 9.46 & 0 & 84.66 & 7.79 & 0 & 65.49 & 2.57 & 0 & 51.58 & 2.41 & 0 & 63.62 \\
\hline S_pct (\%) & 0.07 & 0.01 & 0.34 & 0.1 & 0 & 0.54 & 0.15 & 0 & 1.08 & 0.16 & 0.01 & 1.64 & 0.18 & 0.01 & 1.26 & 0.32 & 0.02 & 4.94 \\
\hline DRAIN_SQKM $\left(\mathrm{km}^{2}\right)$ & 447 & 4.65 & 20,309 & 818 & 2.09 & 28,922 & 1053 & 5.66 & 30,343 & 1,525 & 4.78 & 41,576 & 1472 & 0.26 & 49,999 & 2,119 & 3.43 & 139,505 \\
\hline SLOPE_PCT_30M (\%) & 16.78 & 0.2 & 77.78 & 12.11 & 0.05 & 46.89 & 10.85 & 0.01 & 53.54 & 11.94 & 0 & 63.52 & 5.65 & 0.05 & 51.79 & 5.1 & 0.04 & 47.1 \\
\hline FST32F_BASIN (day-of-year) & 289 & 223 & 331 & 287 & 221 & 325 & 287 & 215 & 330 & 280 & 233 & 368 & 282 & 240 & 367 & 282 & 242 & 345 \\
\hline PPTAVG_BASIN (cm) & 140 & 74 & 355 & 123 & 62 & 234 & 117 & 36 & 160 & 100 & 25 & 160 & 89 & 19 & 132 & 82 & 20 & 166 \\
\hline
\end{tabular}




\section{Appendix 2. Graphical Representation of Invertebrate Response to Total Nitrogen, Total Phosphorus, and Specific Conductance}

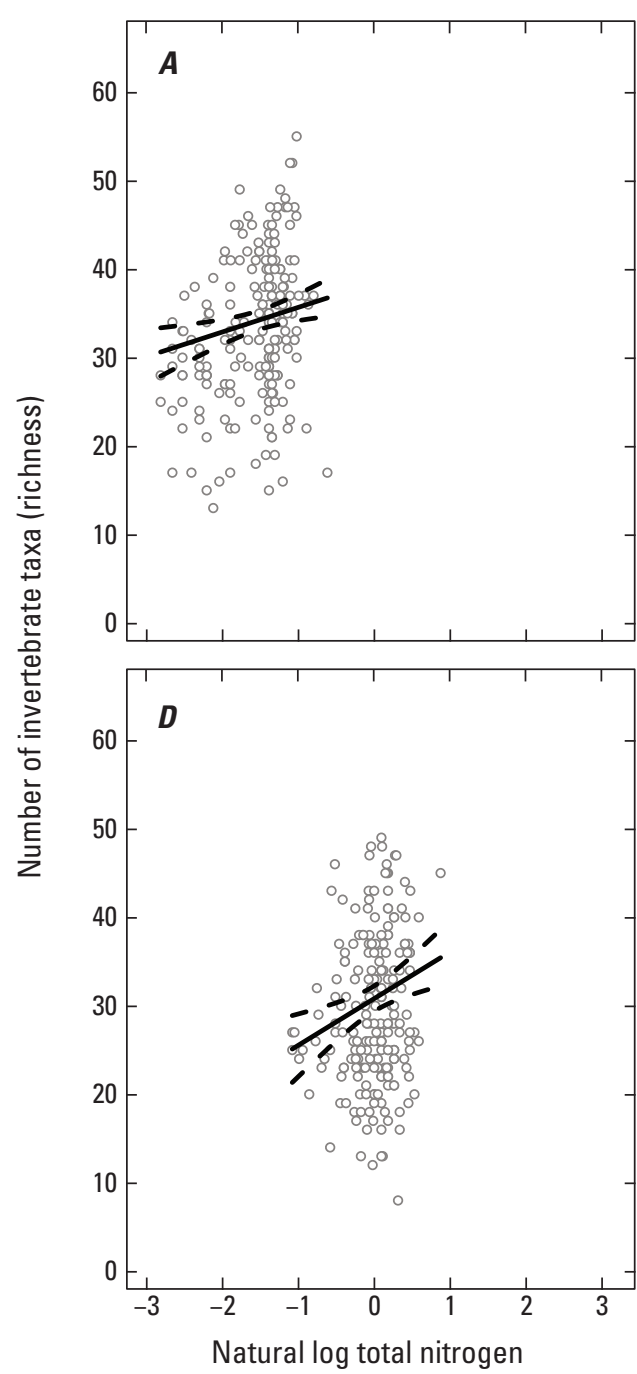

O Observed value
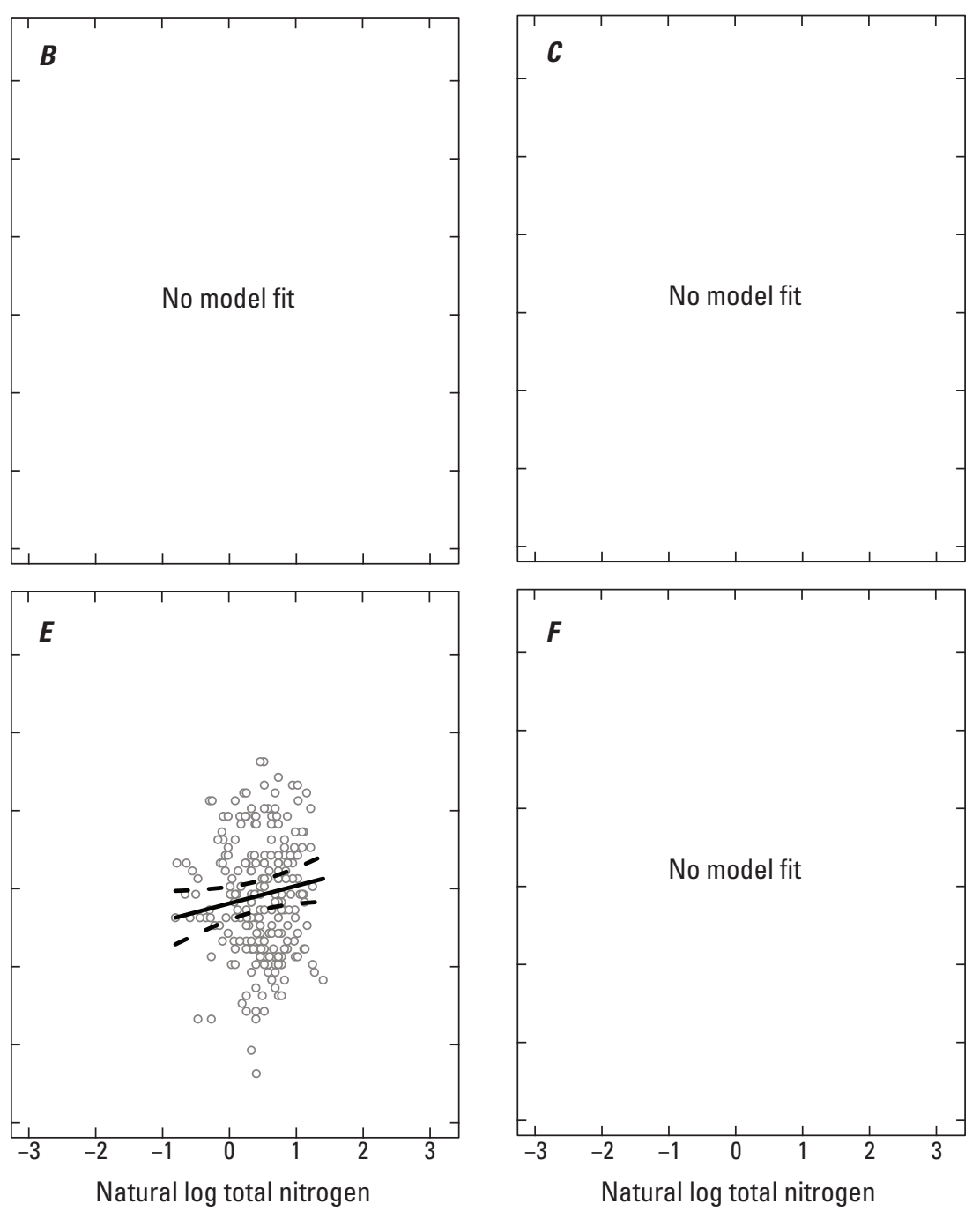

EXPLANATION

Mean estimated linear fit

Figure 2.1. Invertebrate taxa richness plotted against the natural log of total nitrogen for each propensity score-based strata (A-F). Solid lines represent the estimated mean plus or minus two standard errors (dashed lines) from the generalized linear model. No significant model fit in strata $B, C$, and $F$. 


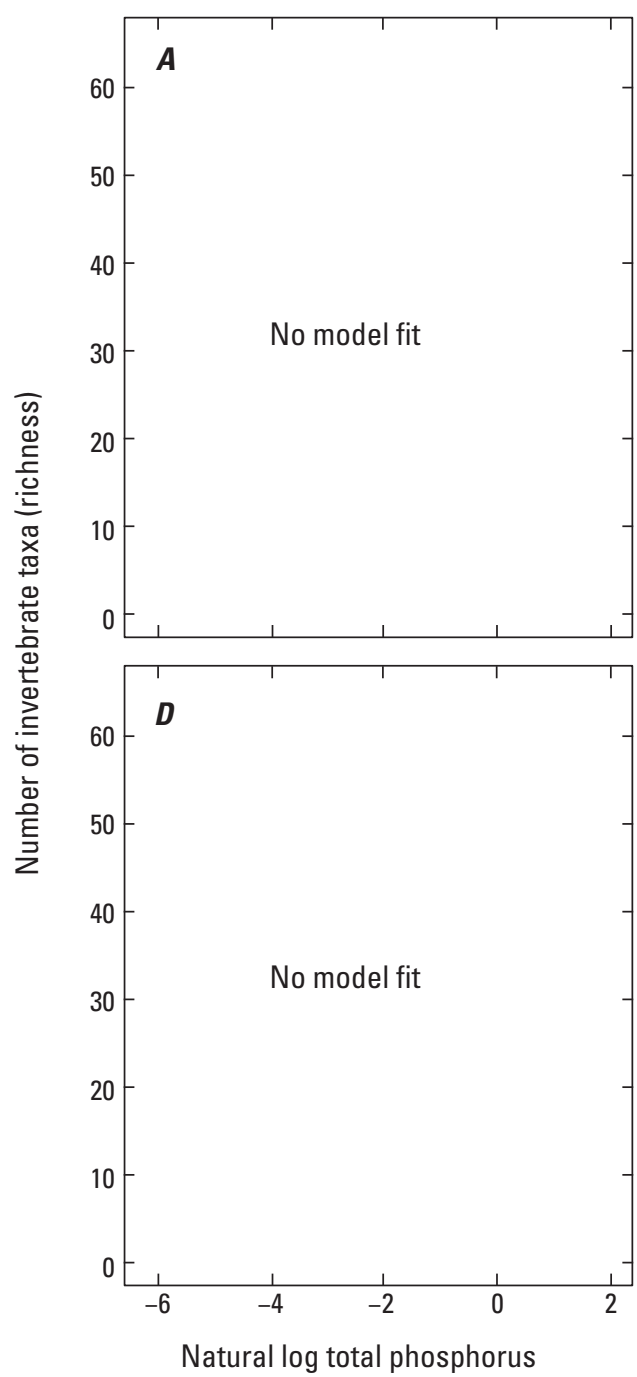

○ Observed value
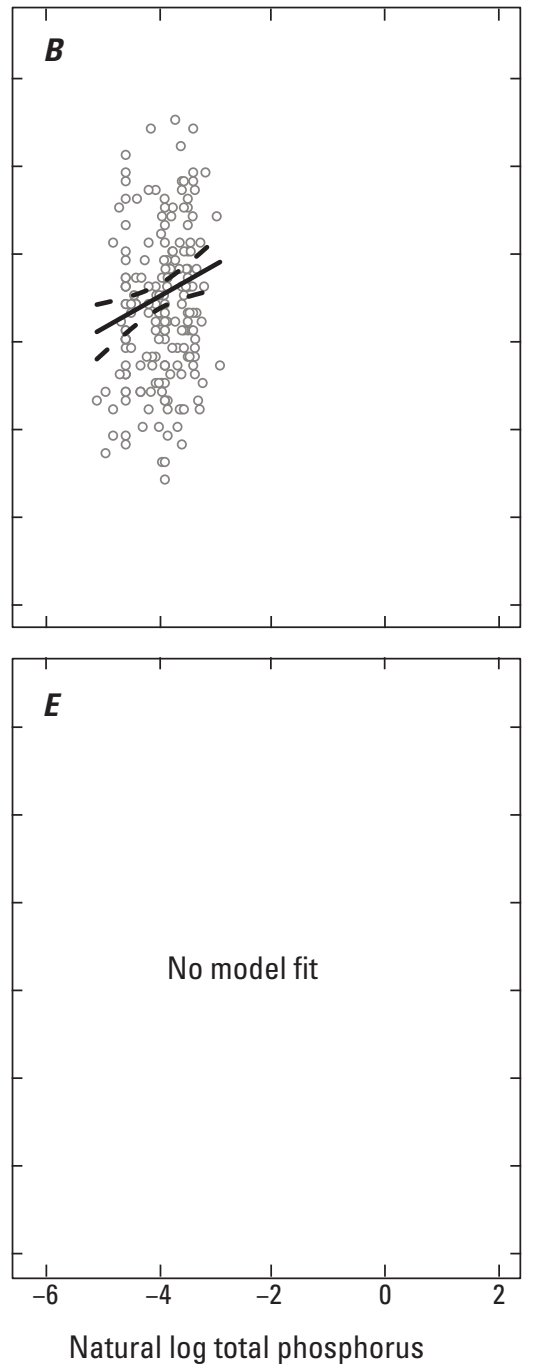

EXPLANATION

Mean estimated linear fit
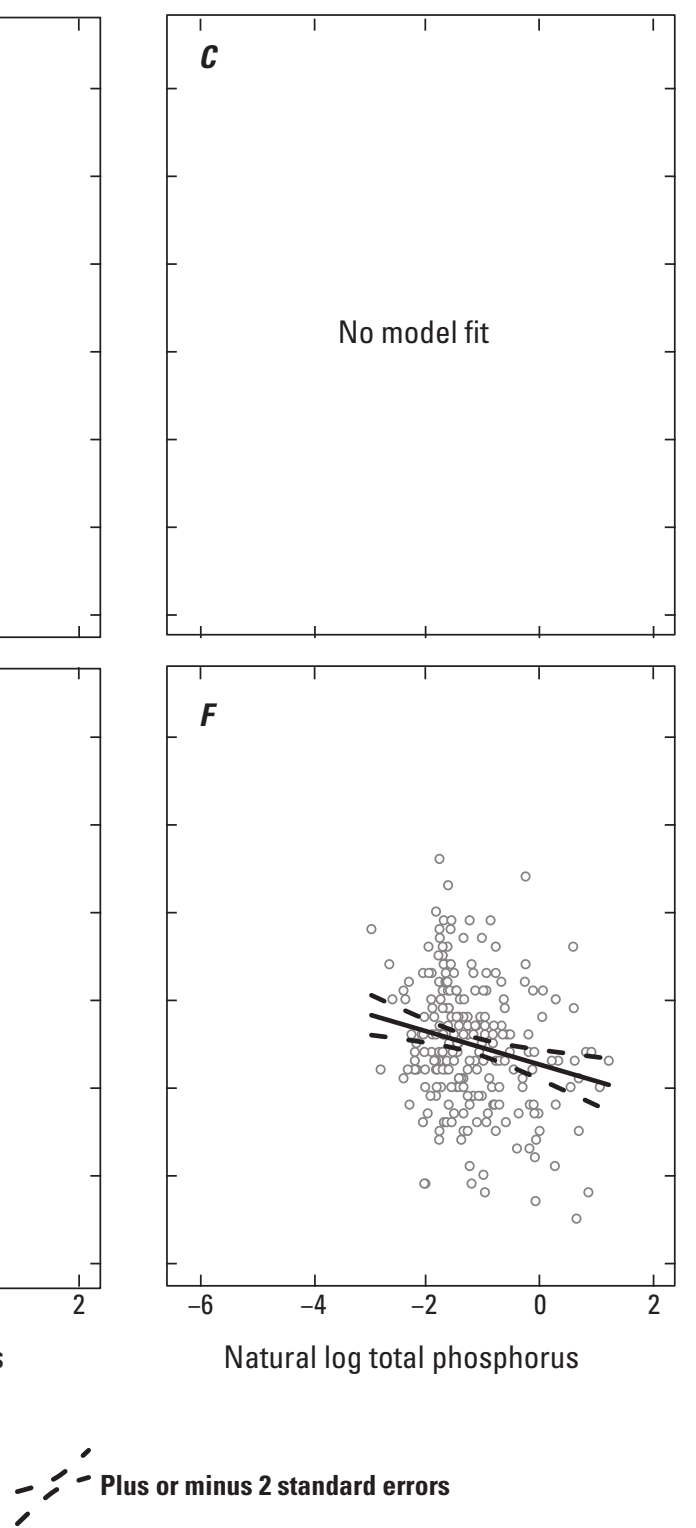

Figure 2.2. Invertebrate taxa richness plotted against the natural log of total phosphorus for each propensity score-based strata (A-F). Solid lines represent the estimated mean plus or minus two standard errors (dashed lines) from the generalized linear model. No significant model fit in strata $A, C, D$, and $E$. 


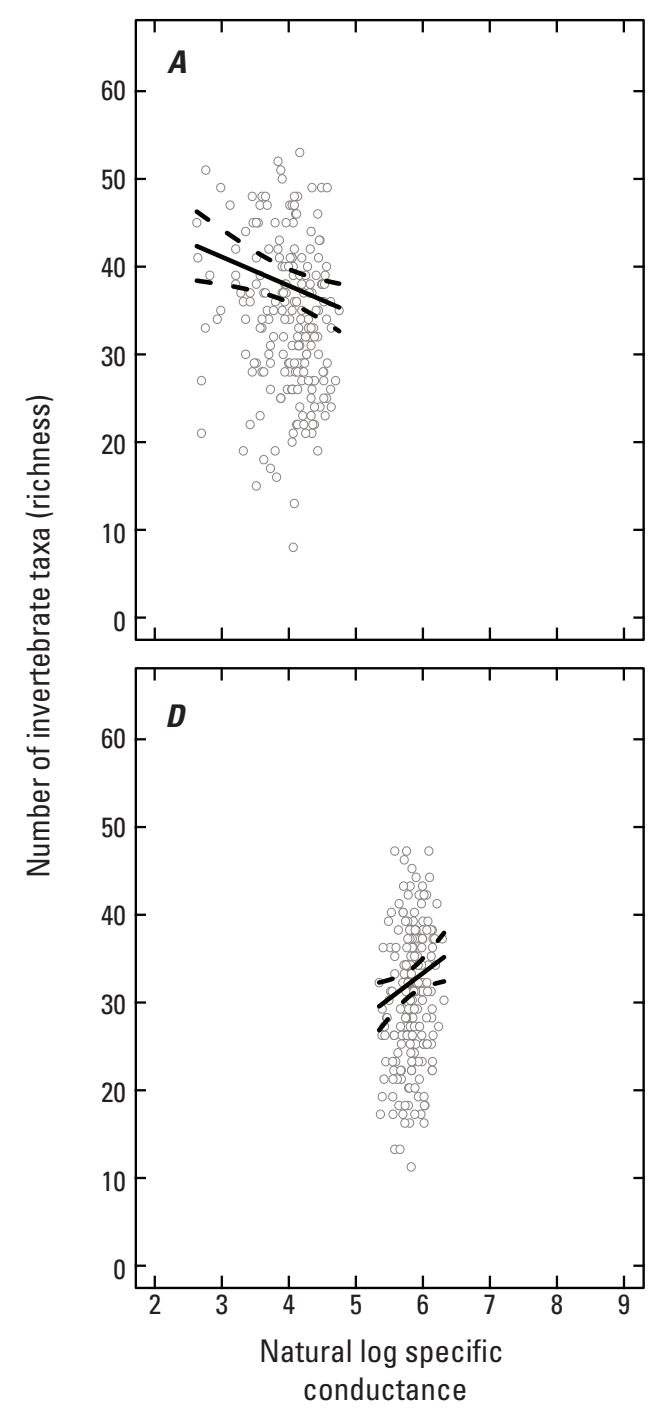

Observed value
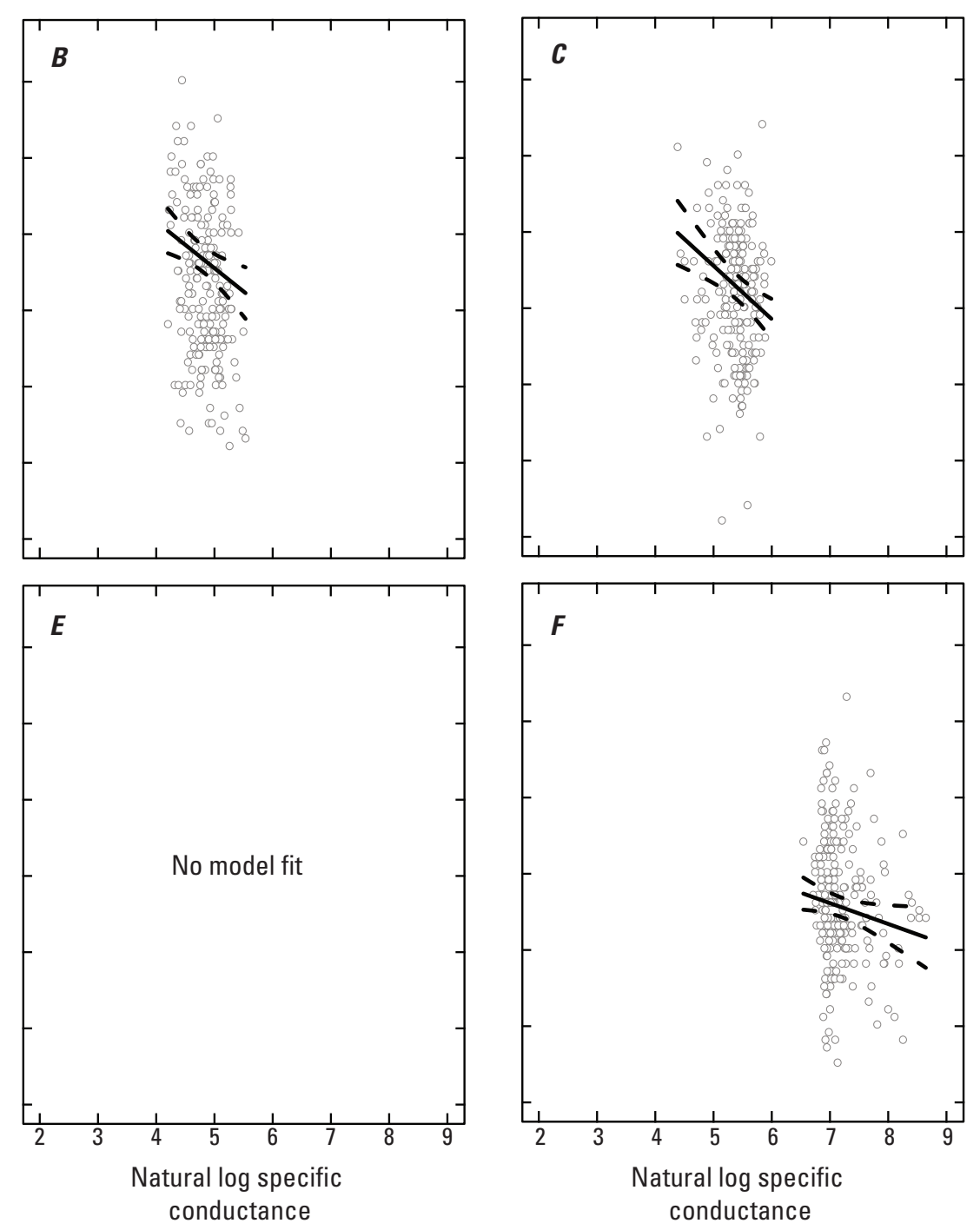

EXPLANATION

Mean estimated linear fit

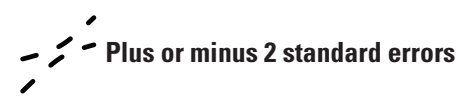

Figure 2.3. Invertebrate taxa richness plotted against the natural log of specific conductance for each propensity score-based strata (A-F). Solid lines represent the estimated mean plus or minus two standard errors (dashed lines) from the generalized linear model. No significant model fit in stratum $\mathrm{E}$. 
Publishing support provided by the Science Publishing Network, Denver Publishing Service Center

For more information concerning the research in this report, contact the

Director, USGS Colorado Water Science Center

Box 25046, Mail Stop 415

Denver, CO 80225

(303) 236-4882

Or visit the Colorado Water Science Center website at https://www.usgs.gov/centers/co-water 


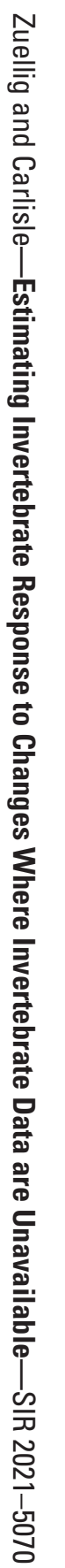

